\title{
Evolution of the Cañadas edifice and its implications for the origin of the Cañadas Caldera (Tenerife, Canary Islands)
}

\author{
E. Ancochea ${ }^{\text {a, * }}$, M.J. Huertas ${ }^{\text {a }}$, J.M. Cantagrel ${ }^{\text {c }}$, J. Coello ${ }^{\text {b }}$, J.M. Fúster ${ }^{\text {a }}$, \\ N. Arnaud ${ }^{c}$, E. Ibarrola ${ }^{a}$ \\ a Depto. Petrología y Geoquímica, Facultad de Ciencias Geológicas, Universidad Complutense, 28040 Madrid, Spain

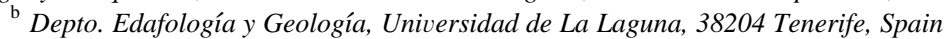 \\ ${ }^{\mathrm{c}}$ Dpt. Géologie, UMR 6524, Univ. Blaise Pascal-CNRS, 5, rue Kessler, 63038 Clermont-Ferrand, France
}

Received 11 November 1997; accepted 14 September 1998

\begin{abstract}
The volcano-stratigraphic and geochronologic data presented in this work show that the Tenerife central zone has been occupied during the last $3 \mathrm{Ma}$ by shield or central composite volcanoes which reached more than $3000 \mathrm{~m}$ in height. The last volcanic system, the presently active Teide-Pico Viejo Complex began to form approximately $150 \mathrm{ka}$ ago. The first Cañadas Edifice (CE) volcanic activity took place between about 3.5 Ma and 2.7 Ma. The CE-I is formed mainly by basalts, trachybasalts and trachytes. The remains of this phase outcrop in the Cañadas Wall (CW) sectors of La Angostura (3.5-3.0 Ma and 3.0-2.7 Ma), Boca de Tauce (3.0 Ma), and in the bottom of some external radial ravines (3.5 Ma). The position of its main emission center was located in the central part of the CC. The volcano could have reached $3000 \mathrm{~m}$ in height. This edifice underwent a partial destruction by failure and flank collapse, forming debris-avalanches during the 2.6-2.3 Ma period. The debris-avalanche deposits can be seen in the most distal zones in the $\mathrm{N}$ flank of the CE-I (Tigaiga Breccia). A new volcanic phase, whose deposits overlie the remains of CE-I and the former debris-avalanche deposits, constituted a new volcanic edifice, the CE-II. The dyke directions analysis and the morphological reconstruction suggest that the CE-II center was situated somewhat westward of the CE-I, reaching some $3200 \mathrm{~m}$ in height. The CE-II formations are well exposed on the CW, especially at the El Cedro (2.3-2.00 Ma) sector. They are also frequent in the S flank of the edifice (2.25-1.89 Ma) in Tejina (2.5-1.87 Ma) as well as in the Tigaiga massif to the $\mathrm{N}(2.23 \mathrm{Ma})$. During the last periods of activity of CE-II, important explosive eruptions took place forming ignimbrites, pyroclastic flows, and fall deposits of trachytic composition. Their ages vary between 1.5 and 1.6 Ma (Adeje ignimbrites, to the $\mathrm{W}$ ). In the $\mathrm{CW}$, the Upper Ucanca phonolitic Unit (1.4 $\mathrm{Ma}$ ) could be the last main episode of the CE-II. Afterwards, the Cañadas III phase began. It is well represented in the CW sectors of Tigaiga (1.1 Ma-0.27 Ma), Las Pilas (1.03 Ma-0.78 Ma), Diego Hernández (0.54 Ma-0.17 Ma) and Guajara (1.1 Ma-0.7 Ma). The materials of this edifice are also found in the SE flank. These materials are trachybasaltic lava-flows and abundant phonolitic lava and pyroclastic flows $(0.6 \mathrm{Ma}-0.5 \mathrm{Ma})$ associated with abundant plinian falls. The CE-III was essentially built between 0.9 and $0.2 \mathrm{Ma}$, a period when the volcanic activity was also intense in the 'Dorsal Edifice' situated in the easterly wing of Tenerife. The so called 'valleys' of La Orotava and Güimar, transversals to the ridge axis, also formed during this period. In the central part of Tenerife, the CE-III completed its evolution with an explosive deposit resting on the top of the $\mathrm{CE}$, for which ages from 0.173 to $0.13 \mathrm{Ma}$ have been obtained. The $\mathrm{CC}$ age must be younger due to the fact that the present caldera scarp cuts these deposits. On the controversial origin of the CC (central vertical collapse vs.
\end{abstract}


repeated flank failure and lateral collapse of mature volcanic edifices), the data discussed in this paper favor the second hypothesis. Clearly several debris-avalanche type events exist in the history of the volcano but most of the deposits are now under the sea. The caldera wall should represent the proximal scarps of the large slides whose intermediate scarps are covered by the more recent Teide-Pico Viejo volcanoes. (c) 1999 Elsevier Science B.V. All rights reserved.

Keywords: volcanic system; Canary Islands; Tenerife; geochronology

\section{Introduction}

Tenerife is the largest island of the Canary Archipelago and has a complex volcanic history. The oldest materials (the Old Basaltic Series, Fúster et al., 1968) appear (Fig. 1) in three independent and deeply eroded massifs: Anaga (to the NE), Teno (to the NW), and Roque del Conde (to the S). Each has been formed in the Upper Miocene and Lower Pliocene as a result of several independent volcanic cycles interspersed with important pauses (Ancochea et al., 1990). The ages published for the Old Basaltic Series are mainly less than $8 \mathrm{Ma}$ although scattered between 11.6 and 3.3 Ma. However, note that the base of the subaerial series has never been dated.

After the Old Basaltic Series, the volcanic activity was concentrated in two large edifices: the central composite volcano of 'Las Cañadas' and the 'Cordillera Dorsal', a SW-NE volcanic ridge linking Las Cañadas Edifice (CE) and Anaga massif (Fig. 1). On each side of the Dorsal, two large trapezoidal depressions have been formed, the so called 'valleys' of Güimar and La Orotava.

On the upper part of the CE, there is a semielliptic depression that measures up to $16 \mathrm{~km}$ in its longest axis, the so called 'Caldera de Las Cañadas' (CC). This depression is partially surrounded (Figs. 1 and 2) by a wall, Las Cañadas Wall (CW) more than $25 \mathrm{~km}$ in length without continuity in the $\mathrm{N}$ and NW sectors. The top of the wall reaches its maximum altitude at Guajara $(2712 \mathrm{~m})$ where the wall also has its maximum height $(500 \mathrm{~m})$. To the East and to the West, the top of the wall lowers while remaining over $2000 \mathrm{~m}$ everywhere. The caldera is classically divided into two large sectors, western and eastern, by the Roques de Garcia, a NW-SE-striking ridge which is partially covered by the recent Teide-Pico Viejo lavas. This caldera is perhaps the most spectacular geologic structure of the Canary Islands, and it is an exceptional place to study the composition and structure of the edifices on which it develops. The 'Cañadas' edifice has always been considered as a complex volcanic structure formed by the superposition of different construction phases (Fúster et al., 1968; Araña, 1971; Coello, 1973; Carracedo, 1975; Ancochea et al., 1989, 1990, 1995; Bravo and Bravo, 1989; Martí et al., 1989a; Martí and Araña, 1991; Navarro and Balcells, 1992).

In the central sector of Tenerife, the most recent activity occurs in the Teide-Pico Viejo complex. Its materials partially fill the Cañadas caldera, proceeding downward to the sea to the North and West and reaching $3718 \mathrm{~m}$ height at the summit of Teide. There are also multiple monogenetic basaltic centres scattered across the island. Some basaltic eruptions have taken place in historical times (the last 500 years).

The radiometric data come from the works of Abdel-Monem et al. (1972), Ancochea et al. (1988, 1989, 1990, 1995), Mitjavila (1990), Martí et al. (1990), Martí and Araña (1991), Ibarrola et al. (1991, 1993), Mitjavila and Villa (1993), Huertas et al. (1994), Fúster et al. (1994) and Martí et al. (1994). Tables 1-3 show the radiometric ages of the $\mathrm{CW}$ and nearby zones, arranged according to the volcanic construction phases and sectors.

The authors of the present paper, after developing a temporal model for the Tenerife island (Ancochea et al., 1990), have presented partial results for the North sector (Ibarrola et al., 1993), for the West side of CE (Fúster et al., 1994) and for the Cañadas Wall (Ancochea et al., 1995). Figs. 3 and 4 show a summary of the stratigraphic model presented by the authors for the different sectors of the Cañadas Edifice and the distribution of the units in the CW. Based on these data, this work presents a general evolution model for the Cañadas Edifice including the genesis of the Cañadas Caldera.

Martí et al. (1994) suggested another stratigraphical, structural and geochronological model based on 


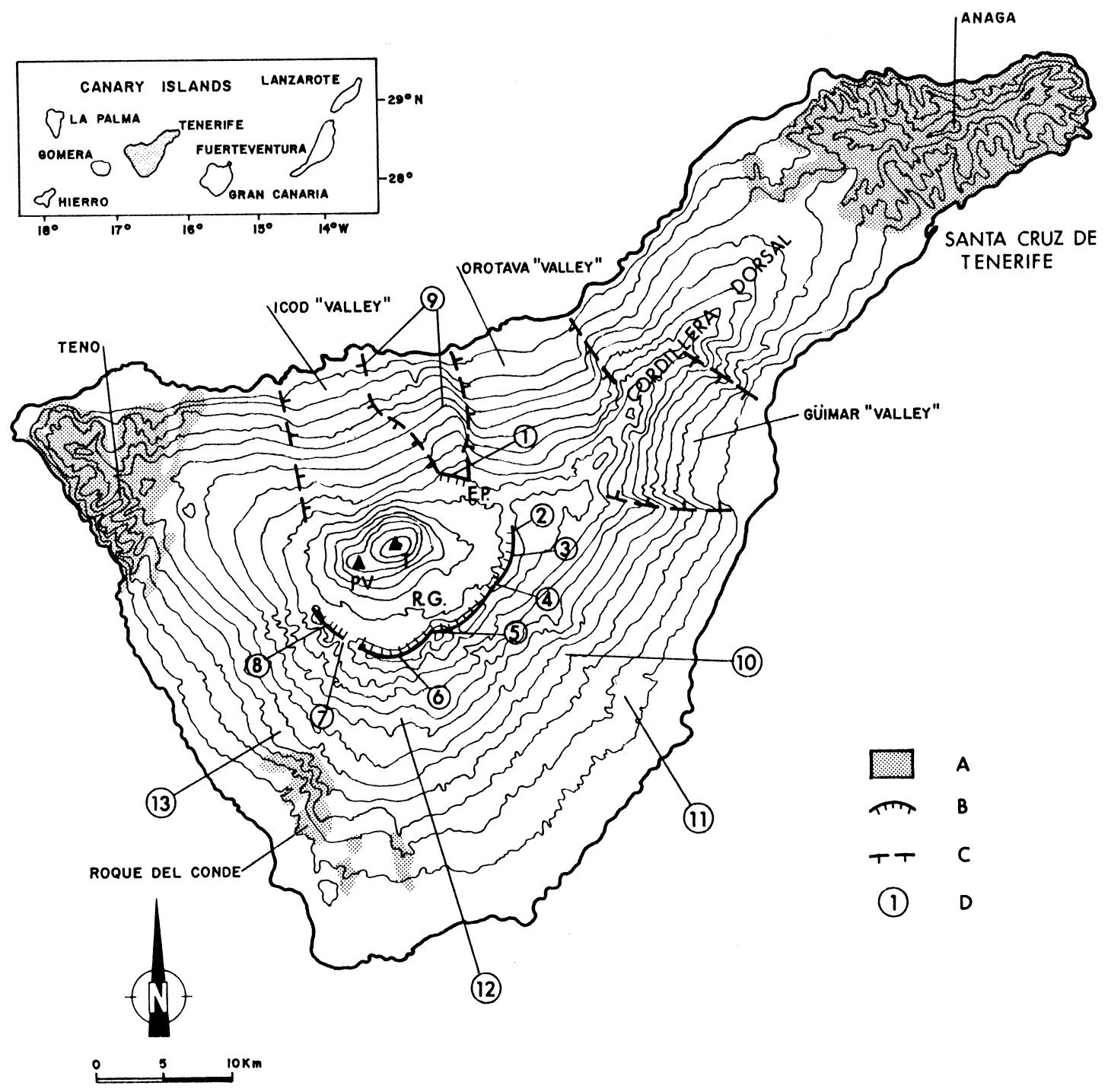

Fig. 1. Distribution of sectors of the Cañadas Edifice. (A) Old Basaltic Series; (B) Caldera rim; (C) Scarps of Orotava, Güimar and Icod 'valleys'; (D) Sectors of the CW and CE: (1) La Fortaleza, (2) Diego Hernández, (3) Las Pilas, (4) La Angostura, (5) Guajara, (6) Llano de Ucanca, (7) Boca de Tauce, (8) El Cedro, (9) Tigaiga, (10) Tamadaya, (11) Arico, (12) Vilaflor, (13) Adeje. T: Teide; P.V.: Pico Viejo; E.P.: El Portillo; R.G.: Roques de García. Contour level intervals 200 m.

Mitjavila (1990) and Mitjavila and Villa (1993). These authors experienced problems of excess argon in basalts from Diego Hernández or dikes and they systematically reject all ages made on basalts. Our model takes into account all ages since all dates generally agree with great consistency. However, when rare problems were encountered on basalts or more salic rocks, especially on feldspars (Fúster et al., 1994 and Ancochea et al., 1995) those are systematically discussed.

\section{Evolution of the Cañadas edifice}

In a previous work (Ancochea et al., 1990) it was thought that the volcanic activity in the $\mathrm{CE}$ was not 

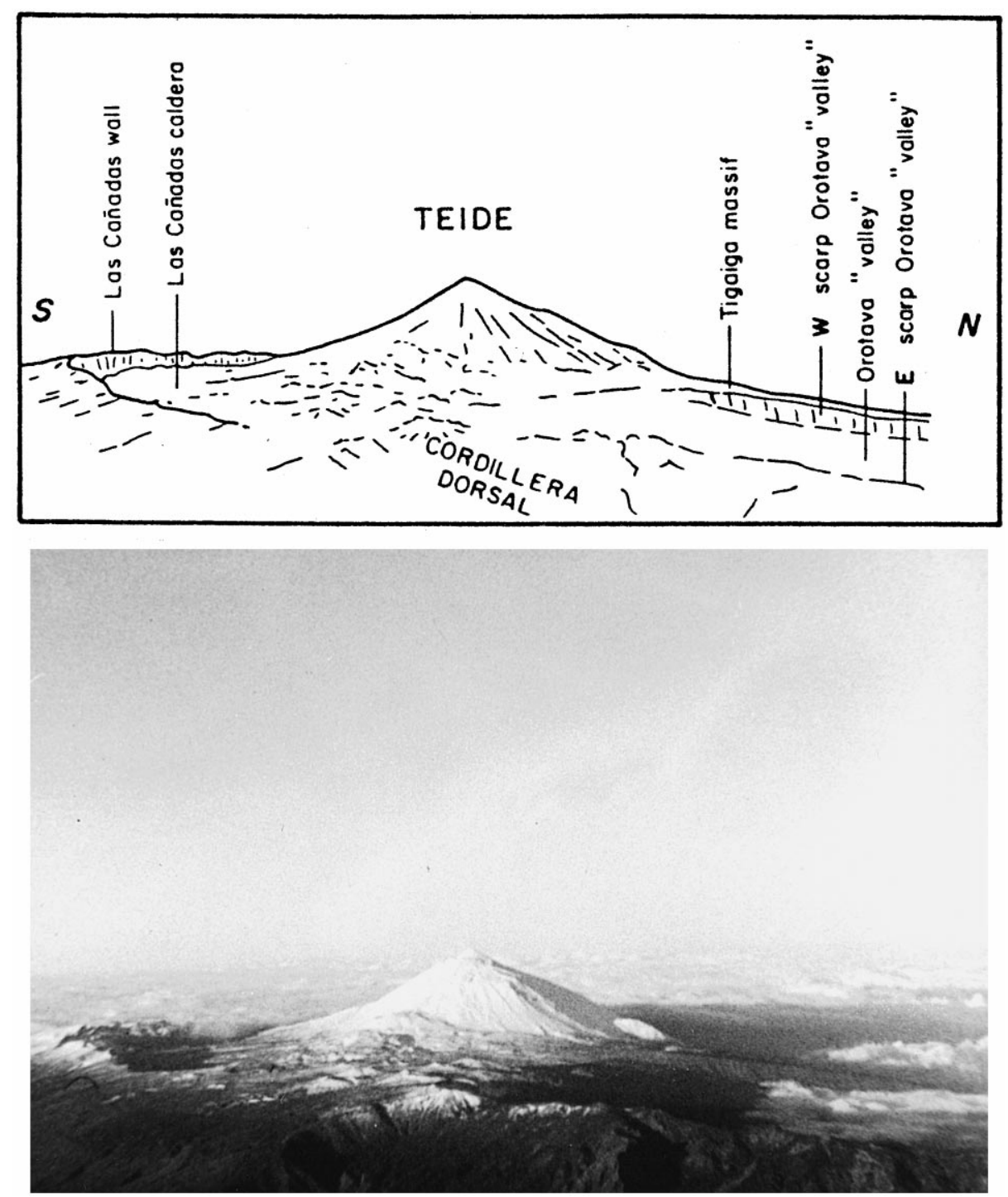

Fig. 2. General aerial view from the NW of the central zone of Tenerife. The snow line marks aproximatively $2000 \mathrm{~m}$ level. The Cañadas scarp is seen at the left. The Cordillera Dorsal is located in the foreground, while the Pico de Teide is to the rear.

older than 2 Ma. However, new field and radiometric data (Ibarrola et al., 1993; Huertas et al., 1994; Fúster et al., 1994; Ancochea et al., 1995) confirm that in the Cañadas present outline the activity has extended for more than $3.5 \mathrm{Ma}$ in several phases of intense volcanic activity separated by phases of erosive destruction and/or of flank failure and formation of avalanches. In each phase, the activity has taken place in centers or edifices located in diverse positions within the $\mathrm{CC}$ limits.

Two main episodes may be distinguished in the evolution of the Cañadas Edifice. Fúster et al. (1968) and Araña (1971) distinguish two series: a Lower Cañadas and an Upper Cañadas. Ancochea et al. (1990) distinguish two edifices: Cañadas I and Cañadas II, that both conclude with ignimbritic 
Table 1

$\mathrm{K}-\mathrm{Ar}$ ages of Cañadas I

\begin{tabular}{|c|c|c|c|c|c|}
\hline Sample no. & Sample type & $\% \mathrm{~K}$ & ${ }^{40} \mathrm{Ar} *(\mathrm{ng} / \mathrm{g})$ & $\% \operatorname{Ar}(\mathrm{atm})$ & $\operatorname{Age}(\mathrm{Ma})(2 \sigma)$ \\
\hline $\mathrm{T}-12-\mathrm{CH}^{\mathrm{c}}$ & Phonotephrite & 3.11 & 0.756 & 46.2 & $3.50 \pm 0.07$ \\
\hline \multicolumn{6}{|c|}{ La Angostura units } \\
\hline $\mathrm{T}-77-\mathrm{A}^{\mathrm{g}}$ & Trachybasalt & 2.76 & 0.639 & 68.4 & $3.34 \pm 0.10$ \\
\hline$T-33-A^{g}$ & Basalt & 2.93 & 0.608 & 63.0 & $2.99 \pm 0.07$ \\
\hline $\mathrm{T}-84-\mathrm{A}^{\mathrm{k}}$ & Trachyte & 4.18 & 0.803 & 40.7 & $2.77 \pm 0.05$ \\
\hline $\mathrm{T}-73-\mathrm{A}^{\mathrm{k}}$ & Trachyte & 3.68 & 0.680 & 53.9 & $2.66 \pm 0.06$ \\
\hline \multicolumn{6}{|c|}{ Boca de Tauce unit } \\
\hline $\mathrm{T}-89-\mathrm{A}^{\mathrm{i}}$ & Basalt & 2.63 & 0.550 & 71.1 & $3.00 \pm 0.10$ \\
\hline
\end{tabular}

a Abdel-Monem et al. (1972).

${ }^{\mathrm{b}}$ Carracedo (1975).

${ }^{c}$ Ancochea et al. (1990).

${ }^{\mathrm{d}}$ Mitjavila (1990).

${ }^{\text {e } M a r t i ́ ~ a n d ~ A r a n ̃ a ~(1991) . ~}$

${ }^{\mathrm{f}}$ Ibarrola et al. (1991).

${ }^{\mathrm{g}}$ Huertas et al. (1994).

${ }^{\mathrm{h}}$ Ibarrola et al. (1993).

${ }^{\mathrm{i}}$ Fúster et al. (1994).

${ }^{j}$ Martí et al. (1994).

${ }^{\mathrm{k}}$ Ancochea et al. (1995).

episodes (Adeje Ignimbritic Unit and Arico Ignimbritic Unit, Fig. 3). Martí et al. (1994) also divide the CE into a Lower Group from 2 to $3 \mathrm{Ma}$ and an Upper Group between 1.56 and $0.17 \mathrm{Ma}$.

\subsection{The Cañadas I Phase (>2.7 Ma)}

\subsubsection{Chronostratigraphy}

In the central zone of Tenerife, the oldest visible materials are 3.5 Ma old (Figs. 3-5). They appear in the $\mathrm{CW}$, in the flanks of the $\mathrm{CE}$ at the bottom of deep radial ravines and in water galleries in the south of the edifice (Huertas et al., 1994). In the galleries, these materials were considered the substratum of the CE (Coello, 1973 and Coello and Bravo, 1989) and were even correlated with the Old Basaltic Series of Teno by Fúster et al. (1968) and Carracedo (1975).

The zone of the CW with the largest superficial development of materials of the Cañadas I Phase is the Cañada of La Angostura (A, Fig. 5). It is a complex sector in which two lithological units can be distinguished: the Angostura Basaltic Unit and the Angostura Trachytic Unit. The first appears in the wall in two zones with a visible thickness of about $150 \mathrm{~m}$; it is formed by a succession of basaltic or trachybasaltic lava flows characterized by the presence of plagioclase hyalobasalts with abundant breccia structures. The ages obtained vary between 3.34 and $2.99 \mathrm{Ma}$ (Table 1, Fig. 4). The Angostura Trachytic Unit is formed by massive, yet fractured, trachytic rocks as well as salic pyroclasts and yields an age between 2.77-2.66 Ma.

In Boca de Tauce (B, Fig. 5) the CW is less high. Here a thick basaltic series outcrops (Boca de Tauce Unit), dipping to the SW. It is formed mainly by basalts or plagioclase hyalobasaltic breccias analogous in composition, position, and age (3.00 Ma, Fúster et al., 1994) to those of La Angostura Basaltic Unit. This unit is cut by dike of several directions, one every $100-150 \mathrm{~m}$, which result in the highest density of dike intrusion in the $\mathrm{CW}$ in agreement with its greater age. 
Table 2

$\mathrm{K}-\mathrm{Ar}$ ages of Cañadas II



References in Table 1.

In the SE external flank of the CC (C, Fig. 5), there are deep radial ravines exposing a lava flows dipping to the SE. The series (Tamadaya Unit) is composed of more than $350 \mathrm{~m}$ of basalts interbedded with some salic rocks (Ancochea et al., 1978). The ages of this unit vary between 3.5 and $3.43 \mathrm{Ma}$. 
Table 3

$\mathrm{K}$-Ar ages of Cañadas III

\begin{tabular}{|c|c|c|c|c|c|}
\hline Sample no. & Sample type & $\% \mathrm{~K}$ & ${ }^{40} \mathrm{Ar} *(\mathrm{ng} / \mathrm{g})$ & $\% \operatorname{Ar}(\mathrm{atm})$ & Age $(\mathrm{Ma})(2 \sigma)$ \\
\hline $\mathrm{T}-46-\mathrm{F}^{\mathrm{c}}$ & Basalt & 2.07 & 0.158 & 84.9 & $1.10 \pm 0.07$ \\
\hline $\mathrm{T}-63-\mathrm{F}^{\mathrm{h}}$ & Phonolite & 3.90 & 0.226 & 57.0 & $0.83 \pm 0.08$ \\
\hline $\mathrm{T}-43-\mathrm{F}^{\mathrm{c}}$ & Trachyte & 3.22 & 0.178 & 78.1 & $0.80 \pm 0.03$ \\
\hline $\mathrm{T}-68-\mathrm{F}^{\mathrm{h}}$ & Trachyte & 3.11 & 0.183 & 64.7 & $0.80 \pm 0.06$ \\
\hline $\mathrm{T}-69-\mathrm{F}^{\mathrm{h}}$ & Phonolite & 4.09 & 0.156 & 73.3 & $0.56 \pm 0.07$ \\
\hline $\mathrm{T}-81-\mathrm{F}^{\mathrm{h}}$ & Trachybasalt & 2.41 & 0.094 & 81.1 & $0.56 \pm 0.03$ \\
\hline $\mathrm{T}-13-\mathrm{CH}^{\mathrm{c}}$ & Phonolite & 4.61 & 0.118 & 95.2 & $0.37 \pm 0.07$ \\
\hline $\mathrm{T}-44-\mathrm{F}^{\mathrm{c}}$ & Basalt & 1.01 & 0.019 & 96.4 & $0.27 \pm 0.07$ \\
\hline $\mathrm{F}-11^{\mathrm{d}}$ & Feldspar & 5.12 & 0.072 & 92.8 & $0.199 \pm 0.018$ \\
\hline DH $-23^{d}$ & Feldspar & 5.88 & 0.205 & 86.6 & $0.496 \pm 0.046$ \\
\hline $\mathrm{DH}-26^{\mathrm{d}}$ & Feldspar & 5.93 & 0.156 & 87.6 & $0.377 \pm 0.032$ \\
\hline $\mathrm{T}-55-\mathrm{A}^{\mathrm{k}}$ & Basalt & 1.47 & 0.045 & 92.6 & $0.44 \pm 0.06$ \\
\hline $\mathrm{DH}-58^{\mathrm{d}}$ & Feldspar & 5.18 & 0.081 & 93.6 & $0.225 \pm 0.052$ \\
\hline DH- $54^{d}$ & Basalt & 1.22 & 0.025 & 96.7 & $0.296 \pm 0.176$ \\
\hline DH-76 ${ }^{\mathrm{d}}$ & Feldspar & 5.35 & 0.067 & 89.8 & $0.178 \pm 0.040$ \\
\hline \multicolumn{6}{|c|}{ Las Pilas unit } \\
\hline $\mathrm{T}-70-\mathrm{A}^{\mathrm{k}}$ & Basanite & 0.475 & 0.034 & 92.9 & $1.03 \pm 0.14$ \\
\hline $\mathrm{TF}-1-\mathrm{CO}^{\mathrm{k}}$ & Phonolite & 3.95 & 0.196 & 83.8 & $0.72 \pm 0.04$ \\
\hline$T-62-A^{k}$ & Phonotephrite & 2.24 & 0.121 & 87.1 & $0.78 \pm 0.06$ \\
\hline $\mathrm{T}-34-\mathrm{A}^{\mathrm{k}}$ & Phonolite & 4.20 & 0.206 & 68.4 & $0.71 \pm 0.02$ \\
\hline \multicolumn{6}{|l|}{ Arico unit } \\
\hline \multicolumn{6}{|c|}{ Guajara unit } \\
\hline ES- $5^{e}$ & Feldspar & 4.62 & 0.381 & 85.4 & $1.18 \pm 0.14$ \\
\hline $\mathrm{T}-12-\mathrm{A}^{\mathrm{c}}$ & Trachybasalt & 3.01 & 0.237 & 77.7 & $1.14 \pm 0.05$ \\
\hline $\mathrm{T}-29-\mathrm{F}^{\mathrm{k}}$ & Phonolite & 4.42 & 0.319 & 73.4 & $1.04 \pm 0.06$ \\
\hline $\mathrm{T}-2-\mathrm{CO}^{\mathrm{k}}$ & Phonolite & 3.03 & 0.189 & 95.4 & $0.90 \pm 0.20$ \\
\hline $\mathrm{T}-95-\mathrm{A}^{\mathrm{k}}$ & Phonolite & 3.80 & 0.228 & 80.9 & $0.86 \pm 0.04$ \\
\hline $9377^{\mathrm{j}}$ & Feldspar & 4.11 & 0.164 & 85.9 & $0.80 \pm 0.10$ \\
\hline $\mathrm{G}-3^{\mathrm{d}}$ & Feldspar & 3.39 & 0.178 & 78.3 & $0.754 \pm 0.022$ \\
\hline$P A-3^{e}$ & Feldspar & 4.89 & 0.243 & 90.4 & $0.712 \pm 0.082$ \\
\hline $93720^{\mathrm{j}}$ & Feldspar & 3.04 & 0.097 & 85.8 & $0.650 \pm 0.024$ \\
\hline $\mathrm{TF}-112^{\mathrm{a}}$ & Phonolite & 3.47 & 0.092 & 42.0 & $0.69 \pm 0.01$ \\
\hline \multicolumn{6}{|c|}{ Another samples } \\
\hline $\mathrm{T}-21-\mathrm{F}^{\mathrm{c}}$ & Trachyte & 2.75 & 0.176 & 82.8 & $0.92 \pm 0.05$ \\
\hline $105^{\mathrm{i}}$ & Feldspar & 5.55 & 0.339 & 55.3 & $0.88 \pm 0.06$ \\
\hline
\end{tabular}


Table 3 (continued)

\begin{tabular}{llllll}
\hline Sample no. & Sample type & $\% \mathrm{~K}$ & ${ }^{40} \mathrm{Ar} *(\mathrm{ng} / \mathrm{g})$ & $\%$ Ar $(\mathrm{atm})$ & Age $(\mathrm{Ma})(2 \sigma)$ \\
\hline Another samples & & & & & \\
T-6-F & Trachyte & 4.12 & 0.190 & 77.0 & $0.67 \pm 0.03$ \\
$\mathrm{~T}-18-\mathrm{F}^{\mathrm{c}}$ & Trachybasalt & 2.66 & 0.118 & 91.5 & $0.64 \pm 0.07$ \\
$\mathrm{~T}-23-\mathrm{F}^{\mathrm{c}}$ & Phonolite & 4.39 & 0.161 & 83.8 & $0.53 \pm 0.04$ \\
\hline
\end{tabular}

References in Table 1.

In an external radial gorge (D, Fig. 5) to the West of the $\mathrm{CE}$ and near the $\mathrm{CW}$, massive and pyroclastic trachytes are frequently cut by dikes (Huertas et al., 1994). A horizontal water gallery that penetrates under them cuts brecciated plagioclase hyalobasalts analogous to those in the Boca de Tauce Unit and in La Angostura Basaltic Unit. In another ravine to the $\mathrm{S}$ of CE (E, Fig. 5), below flows of $2.2 \mathrm{Ma}$ ago, there is another series of breccioid plagioclasic basalts which can be correlated with all those mentioned above.

Finally, in a borehole done in the NW of CC (F, Fig. 5), plagioclase hyalobasalts, which probably represent the NW extension of the Cañadas I Edifice, are found at a depth of a few hundred meters (Coello-Bravo, pers. commun.).

\subsubsection{The Cañadas I Edifice}

The dips of the lava flows denote a source situated in the central part of the island, difficult to be determined precisely without additional data.

Cutting the Cañadas I Phase materials, or the older materials of Roque del Conde of the Old Basaltic Series, there are dikes of very different directions which reasonably must correspond to different centers. If one eliminates those that are coherent with the patterns of dikes cutting later units, the remaining directions are few: $\mathrm{N} 110^{\circ}$ in Boca de Tauce, $\mathrm{N} 30^{\circ}$ in Roque del Conde and $\mathrm{N} 40^{\circ}$ in $\mathrm{La}$ Angostura. These directions converge in a zone situated to the S of Guajara (G, Fig. 5) which could be the approximate position of the emission center. However, a conflict of interpretation arises between the situation of this center $(G)$ and the distribution of outcrops and slopes around it.

The height of the edifice formed in this first phase must have been more than $2300 \mathrm{~m}$ (the height of the outcrops in La Angostura). Assuming an edifice almost circular in shape (although this would never be complete since at least in the SW zone there would be some previous relief of the Old Basaltic Series) with its center approximately in the Cañadas Caldera, its dimensions (Fig. 5) would be of almost $17 \mathrm{~km}$ in radius and $3000 \mathrm{~m}$ in height (for a slope of $9^{\circ}-10^{\circ}$, in the range of the lava shield volcanoes in Hawaii $\left(3^{\circ}\right.$ to $\left.10^{\circ}\right)$ and less than the normal slope $\left(12^{\circ}\right)$ of the big alkaline volcanoes (Peterson and Moore, 1987; Walker, 1993).

The mentioned directions of dikes in the Cañadas I Edifice are also coherent with an edifice build from a 2 or 3 armed rift system (hawaiian type rift zones). It would thus yield a form similar to the present one of Hierro island (Fúster et al., 1993) and this could have strongly influenced the following evolution of the $\mathrm{CE}$, the historic eruptions included as proposed and discussed by Carracedo (1994).

\subsubsection{Relations with the old basaltic series}

As discussed above, the Cañadas I units made up a volcanic edifice centered near the present $\mathrm{CC}$, far from (Fig. 1) the estimated venting points of the old basaltic series of Anaga (NE) and Teno (NW) and therefore without spatial relationship with them.

In the western border of the Anaga massif, the uppermost stratigraphic levels have ages of $3.7 \mathrm{Ma}$ (Carracedo, 1975) and 3.28 and 3.7 Ma (Ancochea et al., 1990) similar to those of the beginning of the Cañadas I. The existence of dikes of similar age in other sectors of the Anaga massif (Féraud, 1981; Ancochea et al., 1990) indicates activity for that period in all the Anaga massif and supports that there is a cycle of activity simultaneous with, but independent of, the early Cañadas I cycle.

There is a 3 Ma gap between the younger basaltic flows of Roque del Conde edifice and the older known Cañadas I volcanic activity. In spite of this 


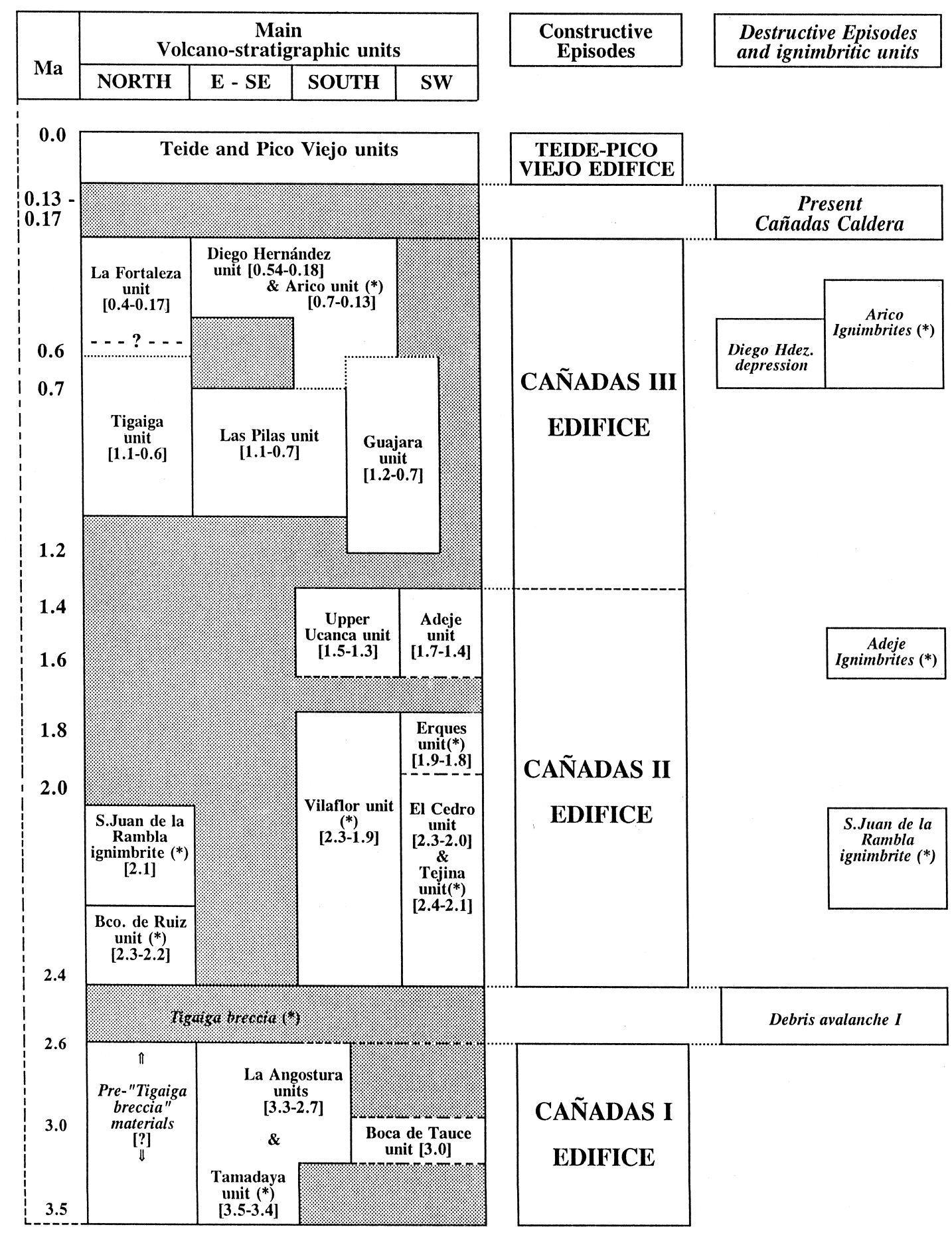

$\left(^{*}\right)$ : Extra-caldera units. []: Radiometric ages range

Fig. 3. Stratigraphic model for the Cañadas Edifice. 


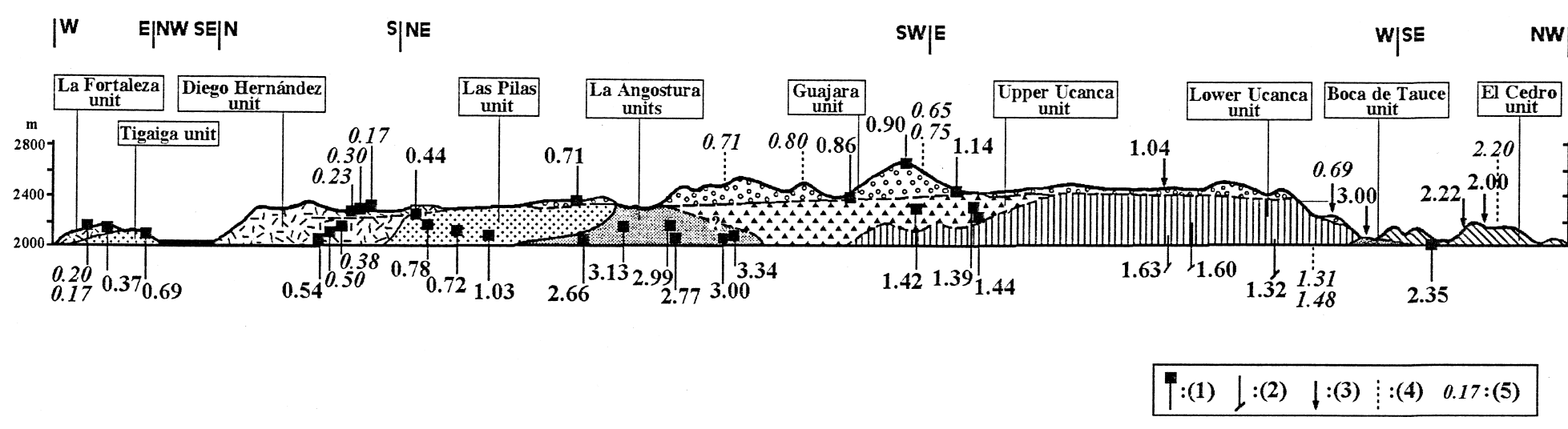

Fig. 4. Scheme of the Cañadas Wall, in which the principle stratigraphic units are indicated as well as the situation of the K-Ar ages. For simplification we have omitted the fractures. (1) Ages of flows in the CW. (2) Ages of dykes in the CW. (3) Ages in the nearby zone of the CW. (4) Ages of dubious position. (5) Ages of another authors. 


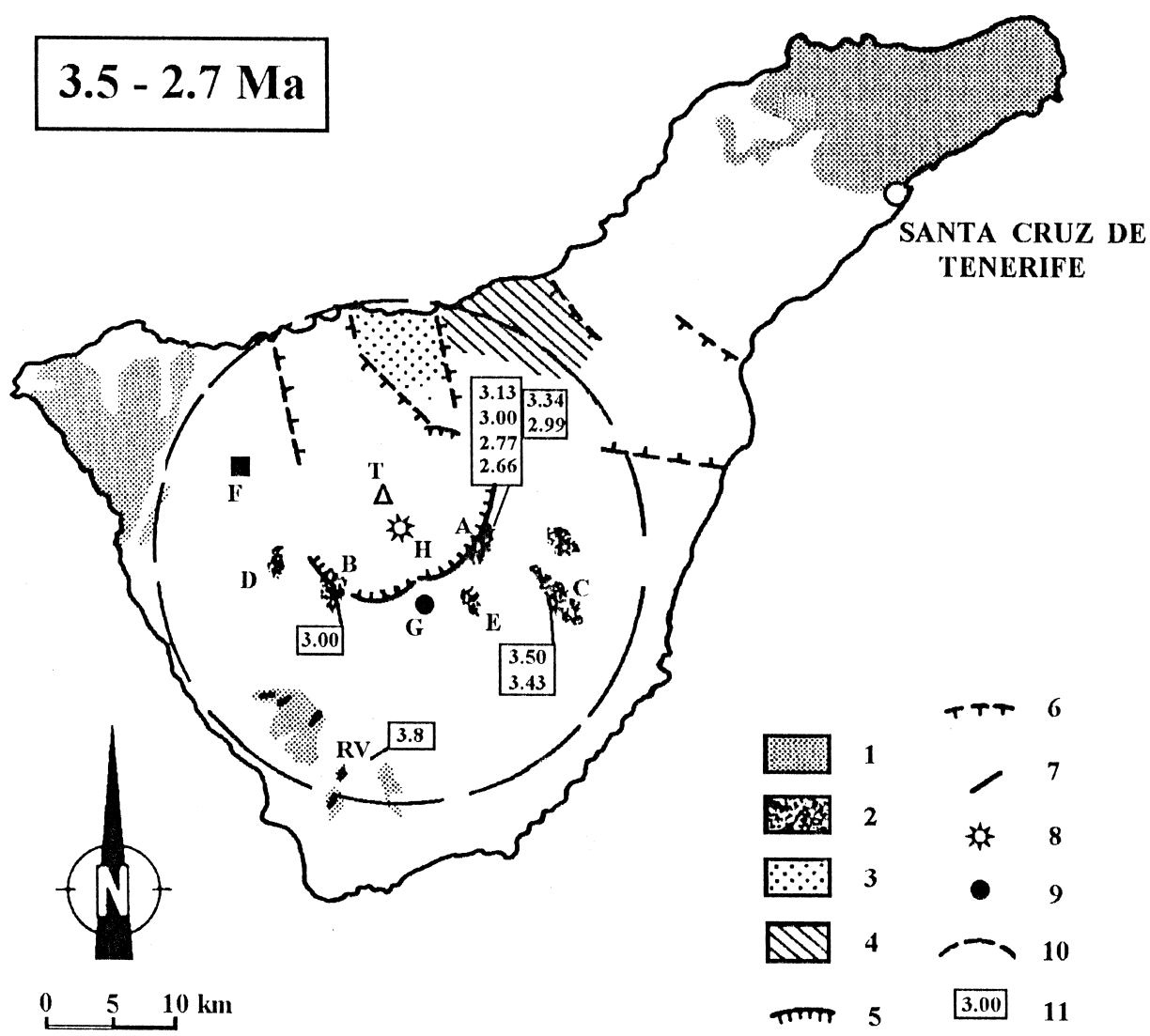

Fig. 5. Reconstruction and ages of Cañadas I Edifice. (1) Old Basaltic Series; (2) Outcrops of the first construction phase of Cañadas Edifice (A: La Angostura; B: Boca de Tauce; C: Barranco de Tamadaya; D: W of El Cedro; E: E of Vilaflor and F: borehole) (3) Tigaiga Breccia; (4) Orotava Breccia; (5) Caldera rim; (6) 'Valleys' scarps; (7) dykes; (8) Center of edifice; (9) Convergence center of the dykes; (10) Possible extension of the edifice; (11) K-Ar ages; RV: Roque del Vento and T: Teide.

temporal gap, there is evidence of a certain spatial overlap. There are several salic plugs that have 'historically' been considered part of the Old Basaltic Series of this sector. Ancochea et al. (1990) dated one of them as 3.8 Ma. This age is older than the Cañadas I Phase yet closer to it than to the other massif rocks whose youngest age is $6.44 \mathrm{Ma}$ (Ancochea et al., 1990). This result suggest a possible link between the plugs and the earliest Cañadas I volcanics, which never outcrop in these southern lower slopes of the island.

There is a good temporal continuity between the Cañadas I activity and the following stages (gap $<0.4$ Ma). In addition the emission centers of Cañadas I, II and III have a similar situation. Both evidences suggest that Cañadas I is a stage of the evolution of the Cañadas edifice evolution independent of the old basaltic series.

The Cañadas I outcrops in CW at $2000 \mathrm{~m}$ above sea level. Thus, is possible that it overlies units contemporary to the old basaltic edifices, either an independent edifice or a part of the Roque del Conde edifice.

\subsubsection{Cañadas I destruction}

After the first phase of activity of the CE, an important destructive period took place which is manifested by the existence of large landslides. To the N, in the Tigaiga massif (Bravo, 1962; Coello, 1973) there is a breccia in the water galleries and below the Barranco de Ruiz Unit which has an age (Ibarrola et al., 1993) of 2.28-2.23 Ma (Fig. 3) 
similar to that of El Cedro Unit. We refer to this unit as the Tigaiga Breccia which was formed, for the most part, by debris avalanche. The materials under that breccia could possibly correspond to the first volcanic activity phase. Unfortunately, the water galleries that allow the observation of these breccias never reach their base.

Where the debris avalanche deposits do not occur in the $\mathrm{CW}$, the Boca de Tauce Unit, (3 Ma) is directly overlain by the El Cedro Unit (2.35-2.0 Ma, see below), indicating an interruption in the volcanic deposits in this sector (Figs. 3 and 4).

The debris-avalanche deposits outcropping mostly in the north of the CE, and the fact that most of the outcrops of the Cañadas I edifice are located to the $\mathrm{S}$ (Fig. 5), indicate the existence of a destruction of the edifice to the North by a flank-failure mechanism.

\subsection{The Cañadas II phase}

Subsequent to the period of destruction represented by the deposits of debris avalanche above mentioned, a second period of activity began in which a well defined central edifice was generated.

\subsubsection{Chronostratigraphy}

The materials of the Cañadas II Phase outcrop mostly in the $\mathrm{S}$ and $\mathrm{W}$ of the $\mathrm{CE}$, in the western sector of the $\mathrm{CW}$, and at the $\mathrm{N}$ of the Tigaiga massif (Fig. 6).

In the western end of the $\mathrm{CW}$, the scarp has less height and is covered by the recent flows of the Teide-Pico Viejo complex that fill the caldera. Above the Boca de Tauce Unit, the El Cedro Unit is formed in its lower part by trachytic and trachybasaltic flows (2.35 and 2.22 Ma). Its upper part is constituted by a succession of thick phonolitic layers reaching a total thickness of more than $180 \mathrm{~m}$ and dipping outward of the CW (2.00 Ma). Martí et al. (1994) report an age for two phonolites from a intermediate layer of $2.2 \mathrm{Ma}$.

In the Llano de Ucanca zone of the CW, under materials that correspond to the Guajara Unit of the Cañadas III Phase (see below), there are two large units: the Upper Ucanca Unit and the Lower Ucanca Unit (Fig. 4). The Lower Ucanca Unit is highly complex due to intense sub-parallel and transverse fracturing and a great number of cross-cutting dikes. In some places, the rocks are also strongly hydrothermally altered ('Los Azulejos deposit') which complicates the stratigraphy and dating.

The host rocks for the dikes are salic pyroclastics, volcanoclastic deposits and debris flows. The stratigraphic relations are not clear. Their age is not well known and has the Boca de Tauce Unit (3.0 Ma) as its lower limit. A phonolite, intruding at a low level of the wall, has been dated at $1.63 \mathrm{Ma} \pm 0.38 \mathrm{Ma}$ and another phonolitic dyke has an age of $1.60 \pm 0.30$ Ma. Both ages, although coherent, have poor precision due to their high percent of atmospheric Ar and possibly argon in excess. Another dyke in the series gave an ${ }^{39} \mathrm{Ar}$ age spectrum which shows evidence of excess argon with an minimum age of 1.4 Ma. The isochron approach (Roddick, 1980) suggests a corrected age of $1.32 \pm 0.03 \mathrm{Ma}$. This age suggest that previous $\mathrm{K} / \mathrm{Ar}$ ages on similar dikes could also be slightly overestimated.

On the external slopes of the $\mathrm{CC}$, the materials of the Cañadas II Phase outcrop abundantly to the S and SW and scarcely to the N. There, only the Barranco de Ruíz Unit, situated over the Tigaiga Volcanic Breccia with an age of 2.28 to $2.23 \mathrm{Ma}$ (Ibarrola et al., 1993), outcrops in the $\mathrm{N}$ of the Tigaiga massif (Fig. 6). The ignimbrite of San Juan de la Rambla which covers the previous sequence has been redated with Ar/Ar. Though showing scatter and possibly excess argon, a plateau with more than $60 \%$ of ${ }^{39} \mathrm{Ar}$ yields an age of $2.11 \pm 0.07 \mathrm{Ma}$ for that ignimbrite, older that the age previously assigned to this unit (1.24 Ma, K/Ar age, Ancochea et al., 1990).

In the $S$ flank of the CE, (Figs. 3 and 6) the thick Vilaflor Unit outcrops underneath the Upper Ucanca Unit, and both are separated by a conglomerate. The unit is divided into two parts: the upper one formed mainly by trachybasaltic and basaltic flows without equivalent in the $\mathrm{CW}(1.89 \mathrm{Ma})$. The lower part composed of intermediate-salic rocks has been dated at 2.25-2.27 $\mathrm{Ma}$ and is equivalent to the El Cedro Unit. Also, underneath, plagioclasic basalts of the first period of activity cropout (Cañadas I).

In the SW flank of the CE, Fúster et al. (1994) established a detailed series (Fig. 3), similar to the previous one, which formed the phonolitic Tejina Unit (2.45-2.07 Ma), which possibly represents a 


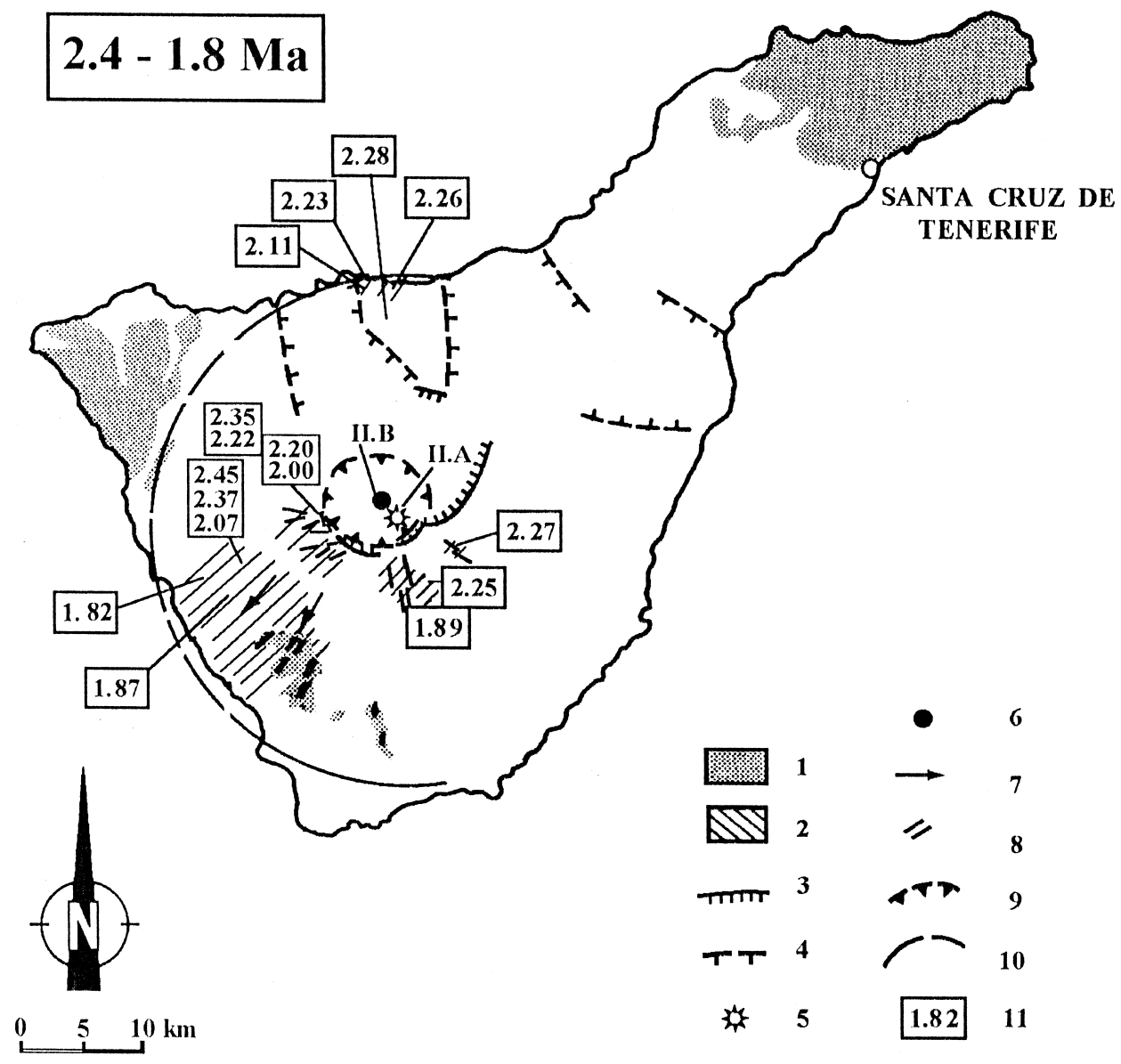

Fig. 6. Reconstruction and ages of Cañadas II Edifice. (1) Old Basaltic Series; (2) Outcrops of Cañadas II Edifice; (3) Caldera rim; (4) 'Valleys' scarps; (5) II.A center; (6) II.B center; (7) Lava-flow directions; (8) Dykes; (9) Cone-sheet; (10) Possible extension of the Cañadas II Edifice; (11) K-Ar ages.

smaller and independent volcanic edifice. Above this unit, basalts and trachybasalts of 1.82 and $1.87 \mathrm{Ma}$ age (Erques Unit) are found.

Between 1.6 and 1.4 Ma, an important volcanic activity developed in the western part of CE (Fig. 7). It is essentially phonolitic. In the $\mathrm{CW}$ this activity is represented by the Upper Ucanca Unit (Figs. 3 and 4). It is covered in unconformity by the Guajara Unit of the Cañadas III Phase. It is formed by phonolitic flows and salic pyroclasts and is cut by far fewer dikes than the underlying units. It outcrops in the eastern part of the wall in the Llano de Ucanca, reaching its biggest thickness in the $\mathrm{W}$ side of Guajara (Fig. 4). Outward of the CW, this unit has a remarkable development above the Vilaflor Unit. It has been dated between 1.48 and $1.39 \mathrm{Ma}$. On the SW flank of the Edifice the Adeje ignimbritic Unit probably represent its equivalent. It is composed of several more or less welded pyroclastic flows, for which ages vary from 1.6 to $1.5 \mathrm{Ma}$ (Fúster et al., 1994).

\subsubsection{The Cañadas II Edifice}

Several dikes outcrop in the CW, most of which are salic and are distributed irregularly. Through these dikes Araña (1971) deduced the existence of two centers, one in each of the two large sectors of the CC. Martí and Araña (1991) and Martí et al. 


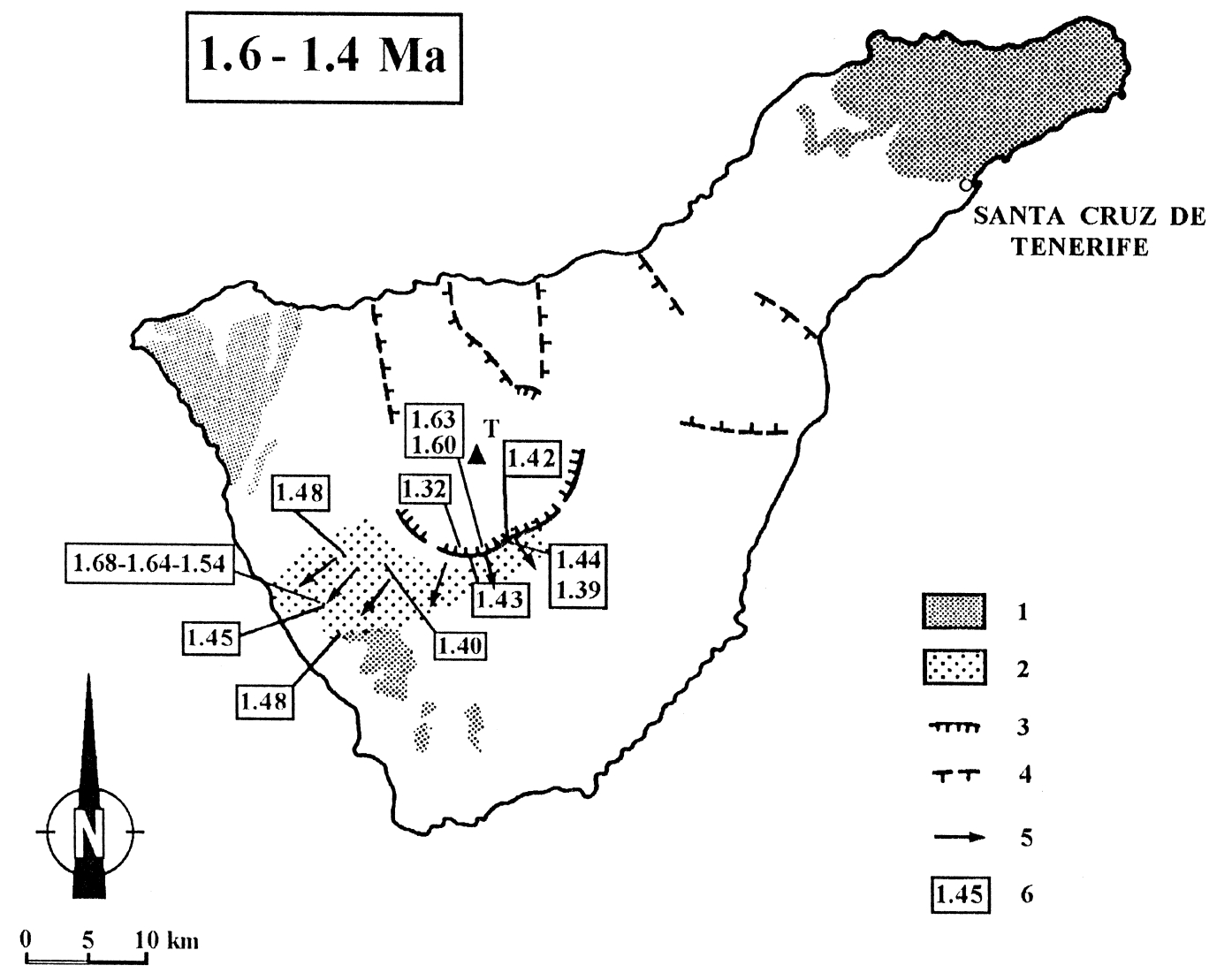

Fig. 7. Distribution and ages of 1.6-1.4 Ma units. (1) Old Basaltic Series; (2) Outcrops of 1.6-1.4 units; (3) Caldera rim; (4) 'Valleys' scarps; (5) Lava-flow directions; (6) K-Ar ages. T: Teide.

(1994) also analyzed the distribution, previously separating the dikes in the eastern part from those in the western part of the CC. Nevertheless, none of the authors analyzed the dikes in terms of the age of the materials they cut. For this reason, their interpretations are based quite possibly on dikes of different ages.

The materials of the Cañadas II edifice are cut by abundant dikes that are more frequent near the proximity of the $\mathrm{CW}$ outside the caldera. The dikes cutting El Cedro and Vilaflor Units show a radial pattern that converges in the interior of the $\mathrm{CC}$, at the Llano de Ucanca, close to the Roques de García (II.A center, Fig. 6). Most of the dikes that cut older units in the caldera (Boca de Tauce and Roque del Conde Massif) converge also to the same center. On the other hand, in the $\mathrm{CW}$ to the $\mathrm{W}$ of Boca de Tauce, two families of dikes separated by approxi- mately $20^{\circ}$ can be seen in detail. Some converge to the center mentioned before (II.A center), while others converge to another center (II.B center), situated some $2 \mathrm{~km}$ to the $\mathrm{NNW}$ of the preceding one.

The dikes that cut the Lower Ucanca Unit have several directions. The first and most important one is constituted by a group of dikes dipping between $40^{\circ}$ and $70^{\circ}$ to the interior of the CC interpreted as belonging to a cone-sheet (Nuez et al., 1989). They essentially outcrop in a belt $0.7 \mathrm{~km}$ wide in which a dyke can appear every $5 \mathrm{~m}$. In the Roques de García, these dikes continue $1.5 \mathrm{~km}$ more into the CC (Figs. 6 and 8), but nevertheless they do not seem to continue on the exterior. Only one third of the possible cone-sheet can be observed (from $\mathrm{N} 105^{\circ}$ to $\mathrm{N} 225^{\circ}$, referred to the theoretical center, Fig. 8) since all the remaining parts are covered by recent materials. 


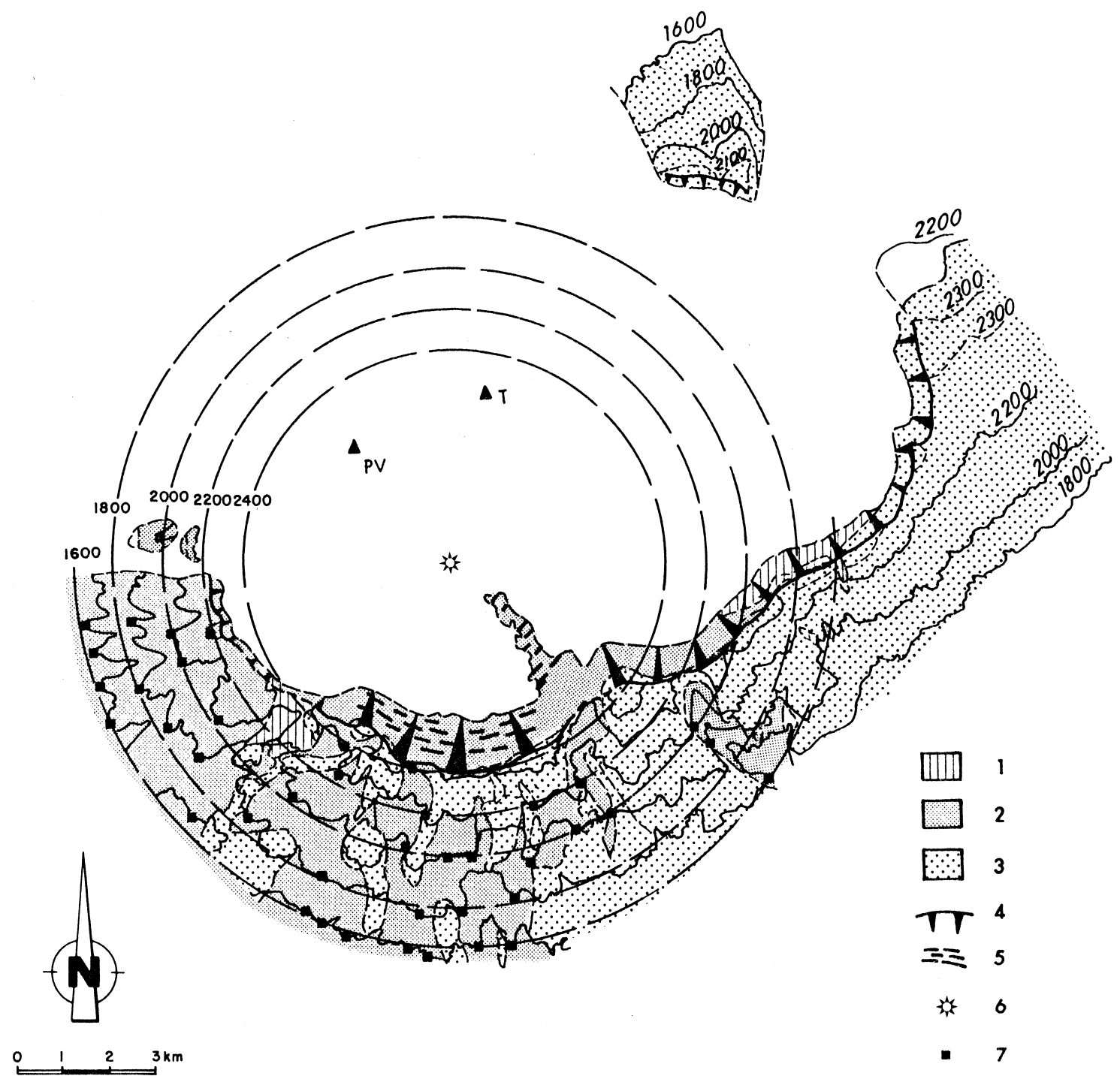

Fig. 8. Border of the Cañadas Caldera and reconstruction of Cañadas II Edifice. (1) Cañadas I materials; (2) Cañadas II materials (including Roques de García Breccia and Ucanca Units); (3) Cañadas III materials; (4) scarp of Cañadas; (5) cone-sheet; (6) II.B center is deduced by the orientation of the dykes; (7) Most distant points from the II.B center in each level contour in Cañadas II materials. The circles represent the level contours of the conical edifice situated at the II.B center. These theoretical contours are exterior tangent to the real level contours. T: Teide and PV: Pico Viejo.

The projection on the surface of the normals to the dikes converge at a point. This point is equivalent to the point of convergence for the radial dikes appearing in the same zone and the second family of radial dikes in the El Cedro Sector. Therefore, it can be inferred that it deals with an actual cone-sheet and not with possibly displaced and tilted dikes.
The geometry of this cone-sheet indicates a salic magma chamber, between 3.5 and $11 \mathrm{~km}$ deep under the Llano de Ucanca. However, for the most frequent dips, the chamber would be at $4 \mathrm{~km}$ depth. This is in agreement with the depth suggested by Wolff (1985) and Ablay et al. (1998) on petrologic grounds for the phonolitic magma chamber. 
The distribution of these dyke families implies that the Cañadas II Edifice as a whole must have been a central volcano built on the remains of the edifice of the former phase or on older materials, that did not extend to the E and SE (Figs. 4 and 6) possibly due to residual relief. Provided that the center of the edifice is in the zone of convergence of the dikes, we can deduce from the distribution of the materials (Fig. 6) that it could have reached a radius of $20 \mathrm{~km}$ and a height of at least $2265 \mathrm{~m}$, the present altitude of El Cedro. If the slope were about $9^{\circ}$, it could have reached $3200 \mathrm{~m}$.

The morphology of the approximately circular edifice can still be recognized in the circular topographic pattern of the eastern exterior sector of the CC (Fig. 8). For each zone and for the same contour line, the most distant point from the theoretical center of the edifice will be at the closest height to the primitive surface. The positions of those points show that, for each contour, they are included in one approximate circular contour line of a theoretical conical edifice whose center would be at the point where the second family of radial dikes and the cone-sheet (II.B center) converge.

This morphological reconstruction confirms the position of the center of the edifice deduced by the convergence of dikes. It also allows us to estimate the height more accurately since the slope between 1600 and $2400 \mathrm{~m}$ can be calculated at $12^{\circ}$. Additionally maintaining a constant slope, the edifice would reach some $3400 \mathrm{~m}$ in the center. This altitude could be even greater with progressive increases in the slope at higher altitudes. This phenomenon is frequent in large strato-volcanoes, such as El Teide.

Martí et al. (1994) distinguish in their Lower Group ( 2 to $3 \mathrm{Ma}$ ) seven sequences. Those seven sequences and the phases described in this paper do not correspond closely: Las Angosturas and Boca de Tauce belong to Cañadas I; El Cedro and the Ucanca sequence belong to Cañadas II; finally the remaining sequences belong to Cañadas III (see below).

\subsection{The Cañadas III Phase (1.1-0.15 Ma)}

After the emission of the Upper Ucanca Phonolitic Unit came a period of minor activity defined in many places by a unconformity. The oldest later materials are not older than $1.14 \mathrm{Ma}$.

\subsubsection{Chronostratigraphy}

The materials of the CE third activity phase gain their largest extension and thickness in the eastern part of the edifice (Fig. 9).

In the Tigaiga massif, the Tigaiga Unit lies unconformably upon the San Juan de la Rambla Ignimbrites constituting most of the massif with ages between 1.1 and 0.69 Ma (Ibarrola et al., 1993). Over that unit, phonolites $(0.56$ and $0.37 \mathrm{Ma})$ and basalts $(0.27 \mathrm{Ma})$ occur. Finally, over all of them, there are salic pyroclastic units, with fragments of nephelinic syenites, dated by Mitjavila (1990) at 0.17 and 0.20 Ma.

The Cañada of Las Pilas is (Fig. 4) one of the most homogeneous units (Las Pilas Unit) of all the CW outcrops. It presents approximately $300 \mathrm{~m}$ of lava flows with interbedded levels of salic pyroclasts in minor proportion. The flows, apparently subhorizontal in the $\mathrm{CW}$, descend towards the exterior of the $\mathrm{CC}$ with a general direction of NW-SE. Their ages varies from 1.03 to $0.72 \mathrm{Ma}$ (Ancochea et al., 1995).

The upper part of the Guajara mountain (Fig. 4) consists of large phonolitic sheets, each one almost $100 \mathrm{~m}$ thick (0.9-0.7 Ma), interbedded with levels of salic tuffs (Guajara Unit). In the Cañadas of Las Pilas an equivalent rock has been dated in $0.71 \mathrm{Ma}$. Other phonolites of the upper part of CW (1.04 and 0.69) can be associated with this unit.

The Cañada de Diego Hernández sector is an old depression excavated in the Las Pilas Unit, filled mainly by salic pyroclasts with some intercalated basaltic lava flows (Diego Hernández Unit). The volcanostratigraphy and geochronology of this sector have been studied in detail by Mitjavila (1990), Martí et al. (1989b, 1990) and Mitjavila and Villa (1993). However, the published ages frequently present problems, some of which occur because the samples have an excess of argon (Mitjavila, 1990), while others occur due to a scarce percentage of radiogenic ${ }^{40} \mathrm{Ar}$ related to their rather young age.

The age of these materials can be limited to less than 0.7 Ma by the age of the Las Pilas unit (Fig. 4) situated to the SW, into which the depression was excavated. The largest part of the filling is comprised in $100 \mathrm{ka}$, since the lowest basaltic flow gave ages of 


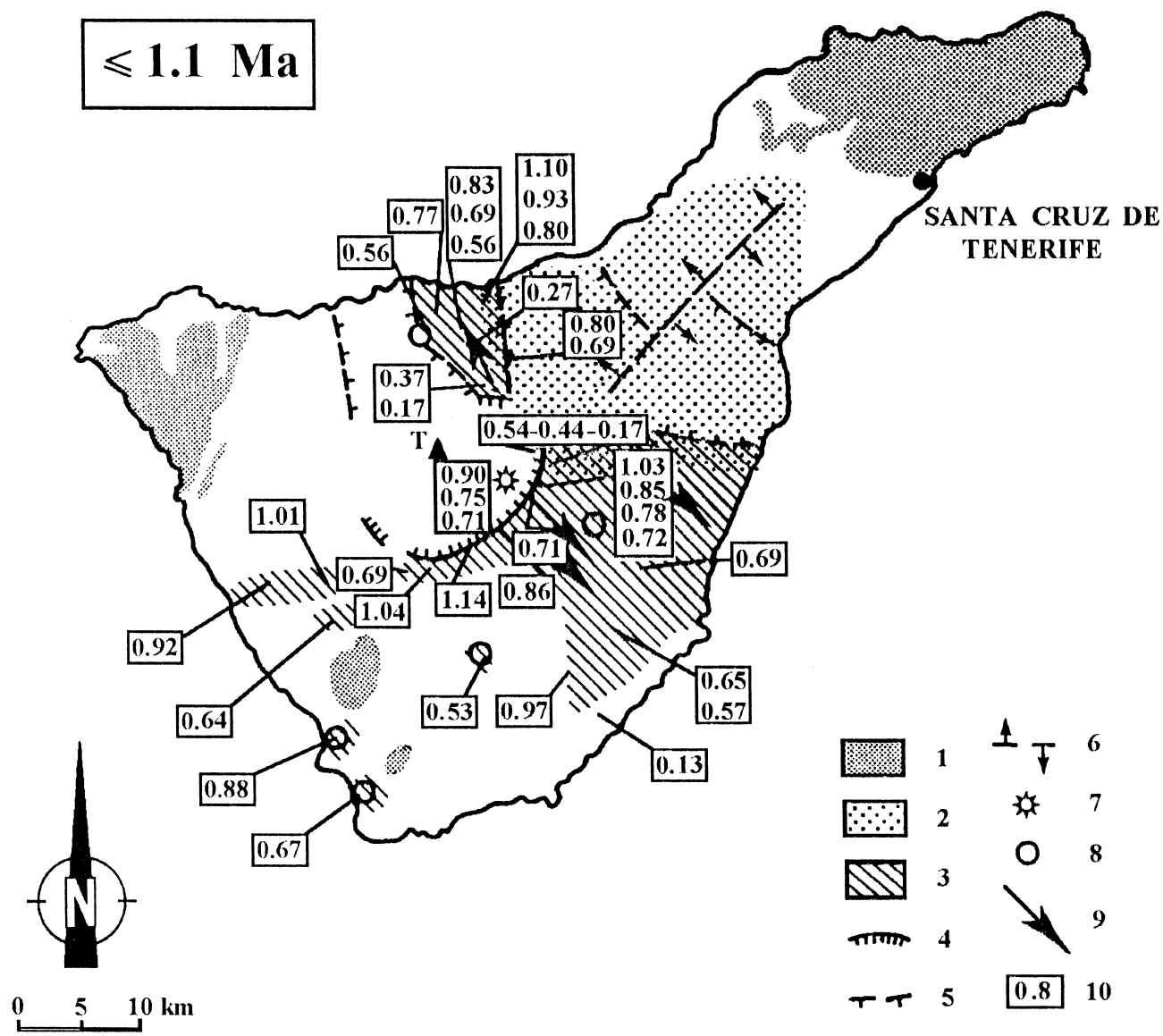

Fig. 9. Distribution and ages of the materials of Cañadas III phase. (1) Old Basaltic Series; (2) Dorsal Edifice; (3) Outcrops of the Cañadas III Edifice; (4) Caldera rim; (5) 'Valleys' scarps; (6) Dorsal Edifice axe; (7) Convergence center of the dykes; (8) Centers of emission of salic rocks in the exterior of the CC; (9) Principal directions of lava-flows; (10) K-Ar ages. T: Teide.

$0.54 \mathrm{Ma}$ (Ancochea et al., 1990; Table 1, Figs. 3 and 4) while a basaltic lava covering the depression in the Las Pilas Unit is 0.44 Ma (Ancochea et al., 1995; Table 1, Fig. 4). Most dates from Mitjavila (1990) on feldspars from pyroclasts interbedded between flows gave ages within these limits.

Over the 0.44 basaltic flow, Mitjavila (1990) dated feldspars at $0.225 \mathrm{Ma}$ and another flow at $0.296 \mathrm{Ma}$. The last level in the Cañada of Diego Hernández is an explosive deposit with fragments of nephelinic syenites that appear also in the top of other sectors of the $\mathrm{CW}$. The ages obtained from this level give between 0.173 and $0.176 \mathrm{Ma}$ (Mitjavila, 1990; Table 1) with the $\mathrm{K}-\mathrm{Ar}$ method and $0.183 \pm 0.008 \mathrm{Ma}$ and $0.179 \pm 0.018 \mathrm{Ma}$ with the ${ }^{40} \mathrm{Ar} /{ }^{39} \mathrm{Ar}$ method
(Mitjavila and Villa, 1993). This deposit is equivalent to and of the same nature as the above mentioned one on the top of Tigaiga $(0.17$ and $0.20 \mathrm{Ma})$. Probably, it is also the same deposit that outcrops in the SE of Tenerife, dated at $0.13 \mathrm{Ma}$ (Ancochea et al., 1990). Cut by the CW, this unit predates the final episode of formation of the present depression of Las Cañadas Caldera (Ancochea et al., 1990), or is equal to it, if it is a caldera-forming unit (Mitjavila, 1990 and Martí et al., 1990).

The sequence of materials in the outer western part of the CE (Arico unit) is analogous to the series in the $\mathrm{CW}$ just seen. Over the basalts of the first phase of the Tamadaya Unit, (Fig. 3) there is a succession of trachybasalts that can be correlated 
with the Las Pilas unit, one of which was dated at $0.69 \mathrm{Ma}$ (Ancochea et al., 1990). Over the former, there is a succession of salic materials with interbedded basaltic flows, know as 'Bandas del Sur', which can be found in all $\mathrm{E}$ and $\mathrm{S}$ parts of the island and which is formed by phonolitic flows and pumiceous pyroclastic deposits that are also phonolitic. These units have been partially studied by Booth (1973), Wolff and Storey (1984), and Wolff (1985), and in detail by Alonso (1989) and Bryan (1995). Alonso (1989) distinguishes more than 23 levels of plinian falls and 15 pyroclastic flows separated by numerous paleosol horizons, most of them coming from a center situated in the CC. Ancochea et al. (1990) date feldspars of a flow and of the Arico ignimbrite that belong to the middle part of this series at 0.57 and $0.65 \mathrm{Ma}$, respectively (Table 2). Hence, both can be tentatively correlated with the salic pyroclastic layers of the high part of CW in the Cañada of Las Pilas or with the Diego Hernández Unit.

\subsubsection{The Cañadas III Edifice}

While the Upper Ucanca Unit proceeds from a center situated in the Cañadas II Edifice environment, the units younger than $1.1 \mathrm{Ma}$ (Las Pilas, Tigaiga, Guajara and Diego Hernández Units) seem to proceed clearly from one or more other centers.

In the $\mathrm{W}$ and $\mathrm{S}$ sectors of the $\mathrm{CE}$, the materials of the third (Cañadas III) eruptive episode are scarce. It is clear that they flow from the $\mathrm{CW}$, or proximate zones, and that they come from a sector situated in the interior of the present $\mathrm{CC}$, which indicates that the present caldera would not have existed at that time. The same conclusions can be obtained observing the distribution of units in the CW (Fig. 4). In the western part of the CW (Guajara Unit), the materials of that age appear approximately at a constant height, around $2400 \mathrm{~m}$, and consequently must originate from a center situated at a higher altitude.

The position of the center(s) that correspond to this third phase of the CE from which the Guajara and Diego Hernández Units, the La Fortaleza phonolite and most of the salic pyroclasts of the 'bandas del Sur' proceed, is not clear. A series of salic dikes, that cut especially the Angostura Units and also the Las Pilas unit, converge in a zone situated $2-3 \mathrm{~km}$ to the north of the Cañada of La Angostura (Fig. 9) which could be a center of the $\mathrm{CE}$ during that episode. Its height would be more than $2700 \mathrm{~m}$ (maximum altitude of the Guajara Unit).

In this period, the eruptive activity is also characterized by the existence of salic emission centers which are external to the $\mathrm{CC}$ and by the intense activity of the Dorsal Edifice (Fig. 9). This edifice was essentially built between 0.9 and $0.4 \mathrm{Ma}$ (Ancochea et al., 1990), a period when the 'valleys' of Güimar and La Orotava were also formed.

The slope of the Tigaiga and Las Pilas Units, approximately coincident with the dip of the flows, indicates flow directions similar to those of the Dorsal Edifice (Fig. 9). However, the materials of the Dorsal Edifice are mainly basaltic whereas, in these units, the basaltic materials are interbedded with salic rocks. Thus, these units could represent the intercalation of the basaltic Dorsal Edifice materials with those from other, essentially salic center(s).

The phase III of the CE ends with the formation of the Cañadas Caldera more recently than about 0.15 Ma. However, the activity in the CE does not end. A new phase begins with the construction of the edifices of Teide and Pico Viejo (Ablay and Martí, 1995) which fill most of the CC and Icod 'valley'. These volcanoes represent a fourth activity phase of the $\mathrm{CE}$ that continues at the present time.

The activity of the recent volcanic centers has moved again to the western sector to positions similar to, although somewhat more to the north than, those of the CE. The fact that Pico Viejo is older than the Teide would indicate a migration to the East with the same significance to what happens between the two centers II.A and II.B of the Cañadas II Edifice.

Again in this paper the suggested stratigraphy is different from previous ones (Martí et al., 1994). The two major differences concern the position of the Las Pilas sequence and the El Cabezón sequences, which is equivalent to the Tigaiga Unit. Ages in this work show that both these units do not belong to the 'Lower Group'.

\section{Discussion and conclusions}

\subsection{Debris avalanche episodes}

Very large debris avalanche deposits have clearly been found off the $\mathrm{N}$ coast of Tenerife (Watts and 
Masson, 1995; Masson and Watts, 1995; Masson, 1996; Acosta et al., 1996 and Muñoz et al., 1996) and it is likely that several of these events will have to be looked for in the evolution of the CE. These kind of events are gaining more and more importance in the generation of large depressions in volcanic regions (Chevalier and Bachelery, 1981; Siebert, 1984; Guest et al., 1984; Francis and Self, 1987; Vincent et al., 1989; Cantagrel and Briot, 1990; Begét and Kienle, 1992; Stoopes and Sheridan, 1992; Francis, 1993; Moore et al., 1994, Cantagrel, 1995; Watts and Masson, 1995).

The Tigaiga Breccia found in the underground water galleries in the northern part of Tenerife (see Section 2.1) which formed before 2.3 Ma represent the debris deposits formed by the destruction to the North of the Cañadas I volcanic formations.

The debris-avalanche deposit observed at the bottom of Roques de García (Roques de García and Lower Ucanca units) corresponds to a second episode of that kind in Tenerife. However, the age of this deposit is not clear: it could be related to another younger pre-Teide event, at the end of Cañadas II or during Cañadas III.

In the galleries of the valley of La Orotava, (Bravo, 1962; Coello, 1973; Coello and Bravo, 1989) there is another breccia. This Orotava breccia rests at a higher stratigraphic level than the Tigaiga Breccia and has an age younger then $0.73 \mathrm{Ma}$ (Ibarrola et al., 1993). In one of the galleries of this valley, Carracedo (1975) dated a phonolitic flow interbedded between both breccias, giving $2.3 \mathrm{Ma}$, which is analogous to the Tigaiga Breccia age. Possibly, the Tigaiga Breccia formed a detachment level which later favoured the landslide that formed the valley of La Orotava and the Orotava Breccia itself (Bravo, 1962).

The 'valley' of Icod (Fig. 1) is a depression open to the $\mathrm{N}$, and filled by flows of Teide-Pico Viejo with a thickness that sometimes exceeds $500 \mathrm{~m}$ (Coello, 1973 and Navarro and Farrujia, 1989). It originated with a large slide, similar to the Güimar and the La Orotava 'valleys'. The lack of residues of the CW to the North side, checked by Coello (1973) in the galleries under the Teide-Pico Viejo deposits, suggests that the formation of the present CC could be the consequence of a large slide as proposed by Navarro and Coello (1989). The slide head could approximately fit with the Cañadas wall, and the 'valley' of Icod results from it.

The old breccia formed by the destruction of the Cañadas I Edifice (Tigaiga Breccia) could acted once more as a detachment level for the landslide which formed the Icod valley. In the history of a volcanic edifice, repeated avalanche events are very common. Moreover, they frequently take place successively in similar directions (Siebert, 1984). An example of that in the Canarian Archipelago is the "Caldera de Taburiente' in La Palma island (Ancochea et al., 1994a).

It is noteworthy that a great proportion of these avalanche deposits lie below sea level, where recent marine surveys show that about $1000 \mathrm{~km}^{3}$ of debris are deposited over an area of $5500 \mathrm{~km}^{2}$ of the sea floor (Watts and Masson, 1995; Masson and Watts, 1995).

\subsection{Origin of Las Cañadas Caldera}

The formation mechanisms of the present Cañadas Caldera have long been discussed by Humboldt (1814), Buch (1825), Lyell (1855), and more recently by Hausen (1956), Blumenthal (1961), Bravo (1962), Fúster et al. (1968), McFarlane and Ridley (1968), Ridley (1971), Araña (1971), Coello (1973), Booth (1973), Borley (1974), Navarro and Coello (1989), Ancochea et al. (1990), Martí and Araña (1991), Martí et al. (1994). Models for erosion, collapse, explosion and avalanche are analyzed in these works.

In recent works, the two models that are in discussion are those that assume that the $\mathrm{CC}$ was formed by a great landslide directed to the North (Navarro and Coello, 1989) and those that assume a formation due to multiple vertical collapses (probably three) that triggered circular or ellipsoidal depressions 'formed in response to successive large volume eruptions' (e.g., Martí and Araña, 1991).

In the model of Martí and Araña (1991) and Martí et al. (1994) the first collapse would have taken place at $1.1 \mathrm{Ma}$ (after the so called Upper Ucanca Unit in this paper). The second collapse would have been after the formation of the Guajara Unit and before the Diego Hernández Unit (the latter dated at $0.35 \mathrm{Ma}$ by these authors). The third would have taken place at the same time as pyroclastic deposits 
with fragments of syenites that cap the $\mathrm{CW}$ at different places $(0.17 \mathrm{Ma})$. However, this model and the ages deduced for the formation of the collapses is based on a stratigraphy of the $\mathrm{CW}$ that is not coherent with the geochronologic data. For example, they put in the same unit (their Lower Group) the Boca de Tauce Unit (3.0 Ma), the El Cedro Unit (2.35-2.0 $\mathrm{Ma})$ and the Las Pilas Unit (1.0-0.7 $\mathrm{Ma})$ or the Tigaiga Unit (1.1-0.6 Ma), units of the three edifices formed in three very different time periods.

The chronostratigraphic data presented here allow the clarification of many aspects about the generation and timing of the caldera. Therein, after the first phase of construction of the CE (3.5-2.7 Ma), there was a first large episode of destruction between 2.6 $\mathrm{Ma}$ (age of the youngest materials dated in the Cañadas I Edifice) and 2.3 Ma (age of the first flows after the Tigaiga Breccia).
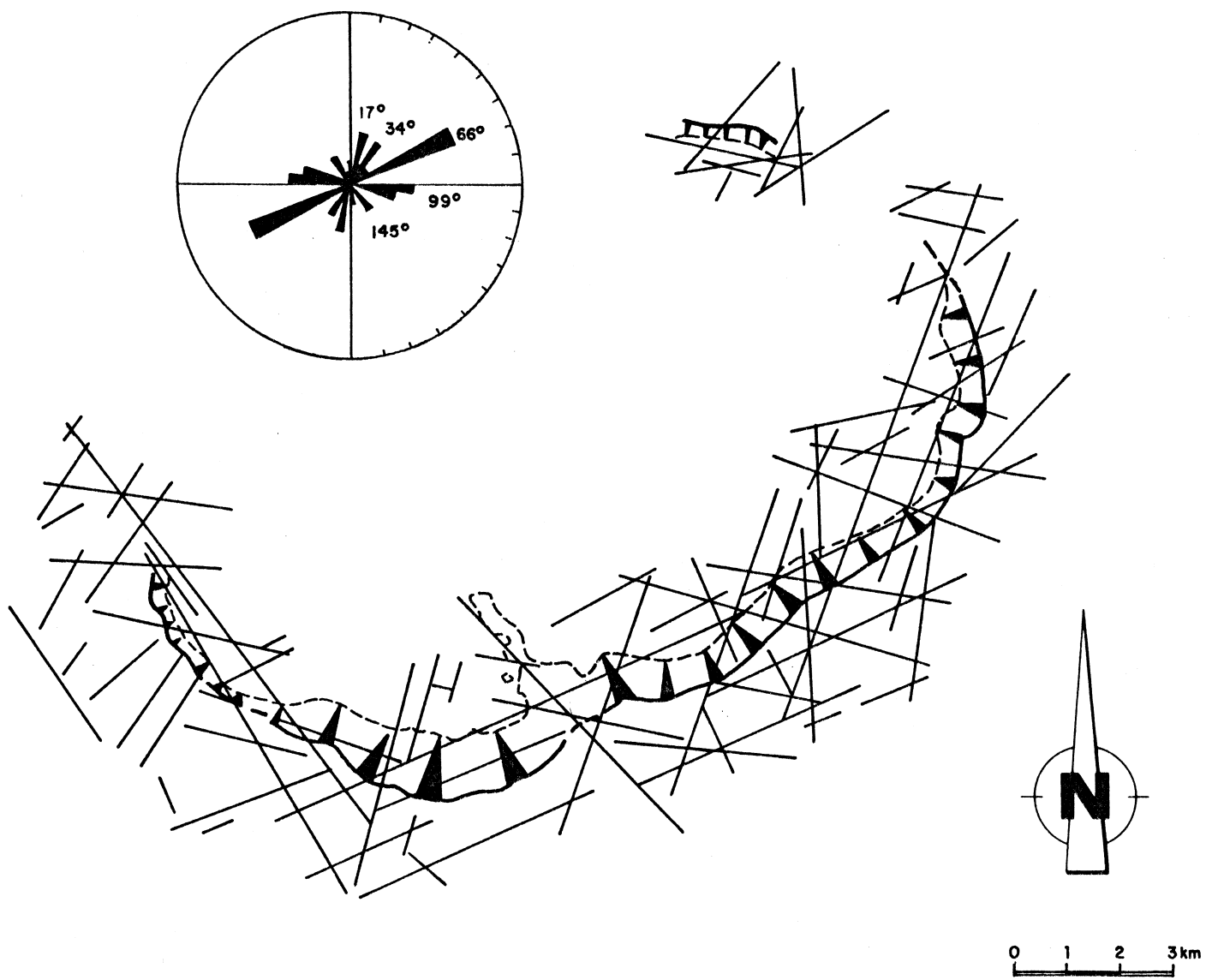

Fig. 10. Principal lineaments in the vicinity zone of the Caldera rim and diagram of their orientations.

Subsequently, during a second effusive period (2.4-1.3 Ma), a large edifice, the Cañadas II Edifice, was constructed centered in the western part of the present $\mathrm{CC}$, an area with which many radial dikes and a possible cone-sheet are associated. The distribution and dip of its deposits, together with the reconstruction of the morphology and the series of dikes, point out the existence of an important central edifice.

The Phase III of the construction of the CE was characterized by the existence of a fissural edifice in the eastern-most part of the present CC (Dorsal Edifice) coexistent with the edifice of central character further to the West (the Cañadas III Edifice). This phase ended with the formation of the present Cañadas Caldera.

The approximate ellipsoidal morphology of the two depressions separated by the scarp of Los Roques
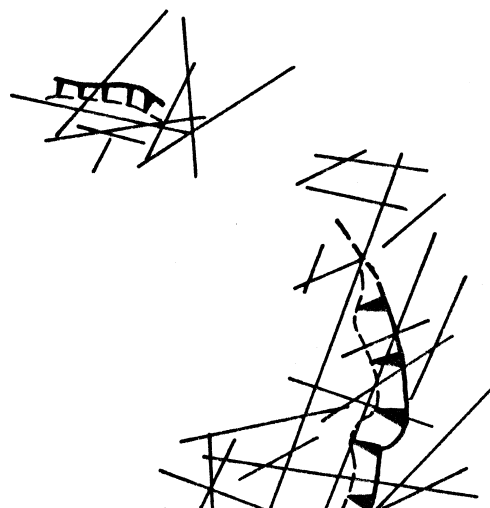
de García (Fig. 8) has been used frequently as the principal argument to establish the hypothesis that both depressions are the result of circular vertical collapses (e.g., Martí and Araña, 1991).

The existence of fundamental directions in the island of Tenerife, deduced essentially by alignments of centers, has been studied by several authors (Araña, 1971; Hernández Pacheco, 1979; Coello and Bravo, 1989; Martí and Araña, 1991). Navarro (1974) and Carracedo (1994) consider that three structural axes meet in the CC, with angles of about $120^{\circ} \mathrm{NE}$ $\left(\mathrm{N} 50^{\circ}\right), \mathrm{S}\left(\mathrm{N} 185^{\circ}\right)$ and $\mathrm{NW}\left(\mathrm{N} \mathrm{300^{ \circ } )}\right.$ that have controlled the island evolution.

Ancochea et al. (1994b) have studied the alignments deduced from the interpretation of aerial and satellite photographs. Fig. 10 is a scheme of the principal lineaments for the zone near the $\mathrm{CW}$ and of the distribution of the most frequent directions. The CW morphology is clearly conditioned by an important network of lineaments (fractures) that frequently are the ascending paths of the magmas of the most recent centers. The most frequent direction is $\mathrm{N}$ $60^{\circ}-70^{\circ}$, which is responsible for the geometry at the SE part of the CW. Further, it coincides with the elliptical elongation, and extends along the Dorsal Cordillera. The second direction is $\mathrm{N} 90^{\circ}-110^{\circ}$ and is responsible for minor aspects of the $\mathrm{CW}$ such as the missing wall in the $\mathrm{NW}$ or the $\mathrm{S}$ edge of Tigaiga massif.

There is no evidence about the formation of a depression later than the Cañadas II Edifice or previous to the one which can be seen today. As a matter of fact, the materials formed in the third effusive episode can be found in the high levels of the CW (Fig. 4). On the other hand, no deposits have been found, on the surface or underground (Navarro and Coello, 1989), filling a depression in the western zone, except the more recent ones of Teide-Pico Viejo. Nevertheless one cannot preclude that the Cañadas II and Cañadas III edifices could have been capped by a large crater or small caldera created for example by the rapid emission of the ignimbritic Adeje flows and 'Bandas del Sur' pyroclastics. However this structure has later been destroyed completely and no portion of this structure seems to be presently preserved in the $\mathrm{CW}$.

If the present $\mathrm{CC}$ has been formed in more than one episode, all of them should have been subse- quent to the Phase Cañadas III and previous to the materials of the Teide-Pico Viejo complex that fill the Caldera.

The explosive deposits, with syenite fragments of $0.17 \mathrm{Ma}$ that are the last level of the $\mathrm{CW}$ and that do not appear inside it, are widely distributed all over the island of Tenerife (Ibarrola and Viramonte, 1967 and Alonso, 1989). They could be interpreted as deposits formed by a big blast possibly due to the sudden drop of pressure in the reservoir and coeval with the formation of the $\mathrm{CC}$ by a large landslide.

New insights about the origin of the Cañadas Caldera will be afforded in the future. At the present time, the data here presented underline the importance of several flank collapse episodes during the evolution of the Cañadas Edifice and are in better agreement with the assumption of the present caldera formation by huge landslides on the volcanic edifices than with the assumption of vertical collapses of the rooves of magmatic chambers related to ignimbritic eruptions.

\section{Acknowledgements}

This work was supported by the Projects: the Spanish DGICYT PB 88-0047 and PB 96-0572 and UCM: PR 219/94-5530. One of the authors, M.J. Huertas, has benefitted from a postdoctoral grant of the subprogram MEC/MRT in Clermont-Ferrand. Critical review and comments from J. Wolff and an anonymous referee helped the authors to improve the original manuscript.

\section{References}

Abdel-Monem, A., Watkins, N.D., Gast, P., 1972. Potassiumargon ages, volcanic stratigraphy and geomagnetic polarity history of the Canary Islands: Tenerife, La Palma and Hierro. Am. J. Sci. 272, 805-825.

Ablay, G.J., Martí, J., 1995. Stratigraphy and structure of the Teide-Pico Viejo volcanic complex. In: Martí, J., Mitjavila, J. (Eds.), A Field Guide to the Central Volcanic Complex of Tenerife (Canary Islands). Serie Casa de los Volcanes, no. 4, 47-80. Cabildo Insular de Lanzarote.

Ablay, G.J., Carroll, M.R., Palmer, M.R., Martí, J., Sparks, S.J., 1998. Basanite-phonolite lineages of the Teide-Pico Viejo volcanic complex Tenerife, Canary Islands. J. Petrol. 39, 905-936.

Acosta, J., Herranz, P., Muñoz, A., Palomo, C., Sanz, J.L., Uchupi, E., 1996. Perfiles sísmicos en el Margen Insular de 
Tenerife: Proyecto Teide, Resultados preliminares. Geogaceta 20, 335-338.

Alonso, J.J., 1989. Estudio volcanoestratigráfico y volcanológico de los piroclastos sálicos del Sur de Tenerife. Col. Investigación, Universidad de La Laguna, 257 pp.

Ancochea, E., Anguita, F., Fúster, J.M., Hernán, F., Coello, J., 1978. Mapa geológico de España, 1:25000. Hoja 1111-IV. Güimar. IGME, 14 pp.

Ancochea, E., Fúster, J.M., Ibarrola, E., Cendrero, A., Coello, J., Hernán, F., Cantagrel, J.M., Jamond, C., 1988. K-Ar chronology of the volcanic eruptions in the Canary Islands. Tenerife. Terra Cognita 6, 158, Abstract.

Ancochea, E., Fúster, J.M., Ibarrola, E., Coello, J., Hernán, F., Cendrero, A., Cantagrel, J.M., Jamond, C., 1989. La Edad del Edificio Cañadas. In: Araña, V., Coello, J. (Eds.), Los volcanes y la caldera del Parque Nacional del Teide (Tenerife, Islas Canarias). ICONA, Madrid, 315-320.

Ancochea, E., Fúster, J.M., Ibarrola, E., Cendrero, A., Coello, J., Hernán, F., Cantagrel, J.M., Jamond, C., 1990. Volcanic evolution of the island of Tenerife (Canary Islands) in the light of new K-Ar data. J. Volcanol. Geotherm. Res. 44, 231-249.

Ancochea, E., Hernán, F., Cendrero, A., Cantagrel, J.M., Fúster, J.M., Ibarrola, E., Coello, J., 1994a. Constructive and destructive episodes in the building of a young Oceanic Island, La Palma, Canary Islands, and genesis of the Caldera de Taburiente. J. Volcanol. Geotherm. Res. 60, 243-262.

Ancochea, E., Brändle, J.L., Huertas, M.J., 1994b. Alineaciones de centros volcánicos en la isla de Tenerife. Geogaceta 17, 55-58.

Ancochea, E., Huertas, M.J., Fúster, J.M., Cantagrel, J.M., Coello, J., Ibarrola, E., 1995. Geocronología de la Pared de la Caldera de las Cañadas (Tenerife, Islas Canarias). Bol. R. Soc. Esp. Hist. Nat. (Sec. Geol.) 90, 107-124.

Araña, V., 1971. Litología y estructura del edificio Cañadas, Tenerife (Islas Canarias). Estud. Geol. 27, 95-137.

Begét, J.E., Kienle, J., 1992. Cyclic formation of debris avalanches at Mt. St. Augustine volcano. Nature 356, 701-704.

Blumenthal, M.M., 1961. Rasgos Principales de la geología de las Islas Canarias con datos sobre Madeira. Bol. Inst. Geol. Min. España 77, 1-13.

Booth, B., 1973. The Granadilla pumice deposit of southern Tenerife, Canary Islands. Proc. Geol. Assoc. 84, 353-369.

Borley, G., 1974. Aspects of the volcanic History and Petrology of the island of Tenerife, Canary Islands. Proc. Geol. Assoc. 85, 259-279.

Bravo, T., 1962. El circo de Las Cañadas y sus dependencias. Bol. R. Soc. Esp. Hist. Nat. (G) 60, 93-108.

Bravo, J., Bravo, T., 1989. Mapa geológico de Las Cañadas del Teide. Tenerife, Islas Canarias. ESF Meeting on Canarian Volcanism. Lanzarote 1989, 201-202.

Bryan, S., 1995. Bandas del Sur pyroclastics, Southern Tenerife. In: Martí, J., Mitjavila, J. (Eds.), A field guide to the Central Volcanic Complex of Tenerife (Canary Islands). Serie Casa de los Volcanes, no. 4, 39-45, Cabildo Insular de Lanzarote.

Buch, L. von, 1825. Physikalische Beschreibung der Canarischen Inseln. Gedruckt in der Druckerei der K. Akademie der Wissenschaften, Berlin, 407 pp.
Cantagrel, J.M., 1995. Avalanches et couleés de débris dans un volcan complexe intraplaque: vers un nouveau schema volcano-structural du massif du Cantal (Massif Central France). Bull. Soc. Geol. Fr. 66 (3), 285-293.

Cantagrel, J.M., Briot, D., 1990. Avalanches et coulées de débris: le volcan du Guéry; oú est la caldéra d'effondrement dans le Massif des Monts Dore? C.R. Acad. Sci. Paris 311, 219-225.

Carracedo, J.C., 1975. Estudio paleomagnético de la Isla de Tenerife. PhD Thesis, Univ. Complutense de Madrid.

Carracedo, J.C., 1994. The Canary Islands: an example of structural control on the growth of large oceanic-island volcanoes. J. Volcanol. Geotherm. Res. 60, 225-241.

Chevalier, L., Bachelery, P., 1981. Evolution structurale du volcan actif du Piton de la Fournaise, Ile de la Réunion, Océan Indien Occidental. Bull. Volcanol. 44, 723-741.

Coello, J., 1973. Las series volcánicas en subsuelos de Tenerife. Estud. Geol. 29, 491-512.

Coello, J., Bravo, T., 1989. Correlación lito-estratigráfica de perforaciones (galerías) en la región central de Tenerife. In: Araña, V., Coello, J. (Eds.), Los Volcanes y la caldera del Parque Nacional del Teide. ICONA, Madrid, 315-320.

Féraud, G., 1981. Datations des réseaux de dykes et de roches volcaniques sous-marines par les méthodes $\mathrm{K}-\mathrm{Ar}$ et ${ }^{40} \mathrm{Ar}-{ }^{39} \mathrm{Ar}$. Utilisation des dykes comme marqueurs de paleocontraintes. Thèse, Univ. Nice, 146 pp.

Francis, P.W., 1993. Volcanoes: a planetary perspective. Oxford Univ. Press. New York, 443 pp.

Francis, P.W., Self, S., 1987. Collapsing volcanoes. Sci. Am. 287, 90-99.

Fúster, J.M., Araña, V., Brändle, J.L., Navarro, J.M., Alonso, V., Aparicio, A., 1968. Geology and volcanology of the Canary Islands: Tenerife. Instituto Lucas Mallada, CSIC, Madrid, 218 pp.

Fúster, J.M., Hernán, F., Cendrero, A., Coello, J., Cantagrel, J.M., Ancochea, E., Ibarrola, E., 1993. Geocronología de la isla de El Hierro. (Islas Canarias). Bol. R. Soc. Esp. Hist. Nat. (Sec. Geol.) 88, 85-97.

Fúster, J.M., Ibarrola, E., Snelling, N.J., Cantagrel, J.M., Huertas, M.J., Coello, J., Ancochea, E., 1994. Cronología K-Ar de la Formación Cañadas en el sector suroeste de Tenerife: implicaciones de los episodios piroclásticos en la evolución volcánica. Bol. R. Soc. Esp. Hist. Nat. (Sec. Geol.) 89, 25-41.

Guest, J.E., Chester, D.K., Duncan, A.M., 1984. The Valle del Bove, Mount Etna: its origin and relation to the stratigraphy and structure of the volcano. J. Volcanol. Geotherm. Res. 21, $1-23$.

Hausen, H., 1956. Contributions to the geology of Tenerife (Canary Islands). Soc. Sci. Fennicae, Comm. Phys. Mat. 18, 254.

Hernández Pacheco, A., 1979. Lineaciones estructurales y vulcanismo en el Archipiélago Canario. III Asam. Nac. Geod. Geof., Madrid, 1565-1589.

Huertas, M.J., Ancochea, E., Cantagrel, J.M., Coello, J., Fúster, J.M., Ibarrola, E., 1994. Un episodio volcánico pre-Cañadas en la Isla de Tenerife. Geogaceta 15, 113-116.

Humboldt, A. Von, 1814. Voyages aux régions equinoxiales du nouveau continent, 1799-1804. Dufour et Cie, Paris, 1, 200 pp. 
Ibarrola, E., Viramonte, J., 1967. Sobre el hallazgo de sienitas nefelínicas en Tenerife (Islas Canarias). Estud. Geol. 23, 215222.

Ibarrola, E., Fúster, J.M., Ancochea, E., Huertas, M.J., 1991. Rocas volcánicas submarinas en la base de la Formación Cañadas, Macizo de Tigaiga (Norte de Tenerife). Geogaceta 9, 17-21.

Ibarrola, E., Ancochea, E., Fúster, J.M., Cantagrel, J.M., Coello, J., Snelling, N.J., Huertas, M.J., 1993. Cronoestratigrafía del Macizo de Tigaiga: evolución de un sector del Edificio Cañadas (Tenerife, Islas Canarias). Bol. R. Soc. Esp. Hist. Nat. (Sec. Geol.) 88, 57-72.

Lyell, C.H., 1855. A manual of elemantary geology. Murray, London, $655 \mathrm{pp}$.

Martí, J., Mitjavila, J., Araña, V., 1989a. Field Trip to Tenerife (Cañadas Caldera). ESF Meeting on Canarian Volcanism. Lanzarote 1989, 1-42.

Martí, J., Mitjavila, J., Barrachina, A., Araña, V., 1989b. El edificio volcánico de Diego Hernández. In: Araña, V., Coello, J. (Eds.), Los volcanes y la caldera del Parque Nacional del Teide (Tenerife, Islas Canarias). ICONA, Madrid, 201-226.

Martí, J., Mitjavila, J., Villa, I., 1990. Stratigraphy and K-Ar ages of the Cañada de Diego Hernández and their significance on the Las Cañadas caldera formation (Tenerife Canary Islands). Terra Nova 2, 148-153.

Martí, J., Araña, V., 1991. Petrology and volcanology of Tenerife. Field Excursion Handbook. CSIC, 93 pp.

Martí, J., Mitjavila, J., Araña, V., 1994. Stratigraphy, structure and geochronology of the Las Cañadas caldera (Tenerife, Canary Islands). Geol. Mag. 131, 715-727.

McFarlane, D.I., Ridley, W.I., 1968. An interpretation of gravity data for Tenerife, Canary Islands. Earth Planet. Sci. Lett. 4, 481-486.

Masson, D.G., 1996. Catastrophic collapse of the volcanic island of Hierro $15 \mathrm{ka}$ ago and the history of landslides in the Canary Islands. Geology 24, 231-234.

Masson, D.G., Watts, A.B., 1995. Slope failures and debris avalanches on the flanks of volcanic oceanic islands-the Canary Islands, off NW Africa. Landslide News 9, 21-24.

Mitjavila, J., 1990. Aplicación de técnicas de geoquímica isotópica y de geocronología al estudio vulcanológico del edificio de Diego Hernández y su relación con la Caldera de Las Cañadas (Tenerife). PhD Thesis, Universidad de Barcelona, 258 pp.

Mitjavila, J., Villa, I., 1993. Temporal evolution of Diego Hernández formation (Las Cañadas, Tenerife) and confirmation of the age of the caldera using the ${ }^{40} \mathrm{Ar}^{39}{ }^{39} \mathrm{Ar}$ method. Rev. Soc. Geol. España 6, 61-65.

Moore, J.G., Normak, W.R., Holcomb, R.T., 1994. Giant Hawaiian landslides. Annual Rev. Earth Plant. Sci. 22, 119-144.
Muñoz, A., Acosta, J., Herranz, P., Palomo, C., Sanz, J.L., Uchupi, E., 1996. Batimetría Multihaz de Tenerife (Islas Canarias): Proyecto Teide-95. Geogaceta 20, 339-342.

Navarro, J.M., 1974. La estructura geológica de Tenerife y su influencia en la Hidrogeología. Simp. Intern. Hidrogeol. Lanzarote, 37-57.

Navarro, J.M., Coello, J., 1989. Depressions originated by landslide processes in Tenerife. ESF Meeting on Canarian Volcanism. Lanzarote 1989, 150-152.

Navarro, J.M., Farrujia, I., 1989. Plan hidrológico insular de Tenerife. Aspectos geológicos e hidrogeológicos. Dirección General de Aguas, Gobierno de Canarias, 145 pp.

Navarro, J.M., Balcells, R., 1992. Parque Nacional del Teide. Mapa Geológico. ICONA, Madrid.

Nuez, J. de la, Cubas, C.R., Hernán, F., 1989. Los domos sálicos del Parque Nacional del Teide. In: Araña, V., Coello, J. (Eds.), Los Volcanes y la caldera del Parque Nacional del Teide. ICONA, Madrid, 177-192.

Peterson, D.W., Moore, R.B., 1987. Geologic history and evolution of geologic concepts, island of Hawaii. In: Volcanism in Hawaii. U.S. Geol. Sur. Prof. Paper, 1350, 149-189.

Ridley, W., 1971. The field relations of the Cañadas volcanoes Tenerife, Canary Islands. Contrib. Mineral. Petrol. 26, 124 160.

Roddick, J.C., 1980. The application of isochron diagrams in ${ }^{40} \mathrm{Ar}-{ }^{39} \mathrm{Ar}$ dating: a discussion. Earth Planet. Sci. Lett. 41, $233-244$

Stoopes, G.R., Sheridan, M.F., 1992. Giant debris avalanche from the Colima volcanic complex, Mexico: implications for longrunout landslides ( $>100 \mathrm{~km}$ ) and hazard assessment. Geology 20, 299-302.

Siebert, L., 1984. Large volcanic débris avalanches: characteristics of source areas, deposits and associated eruptions. J. Volcanol. Geotherm. Res. 22, 163-197.

Vincent, P.M., Bourdier, J.L., Boudon, G., 1989. The primitive volcano of Mont Pelée: its construction and partial destruction by flanc collapse. J. Volcanol. Geotherm. Res. 38, 1-15.

Walker, G.P.L., 1993. Basaltic volcano systems. In: Prichard, H.M., Alabaster, T., Harris, N.B.W., Neary, C.R. (Eds.), Magmatic Processes and Plate Tectonics. Geol. Soc. London. sp. publ., 76.

Watts, A.B., Masson, D.G., 1995. A giant landslide on the north flank of Tenerife, Canary Islands. J. Geophys. Res. 100 (B12), 24487-24498.

Wolff, J.A., 1985. Zonation mixing and eruptions of silica-undersaturated alkaline magma: a case study from Tenerife, Canary Islands. Geol. Mag. 122, 623-640.

Wolff, J.A., Storey, M., 1984. Zoning in highly alkaline magma bodies. Geol. Mag. 121, 563-575. 